\title{
Tomato seeds as a novel by-product feed for lactating dairy cows
}

\author{
C. A. Cassinerio, ${ }^{*}$ J. G. Fadel, ${ }^{*}$ J. Asmus, † J. M. Heguy,‡ S. J. Taylor, ${ }^{*}$ and E. J. DePeters ${ }^{\star 1}$ \\ *Department of Animal Science, University of California, Davis 95616-8521 \\ †January Innovation Inc., 5750 East Harney Lane, Lodi, CA 95240 \\ fUniversity of California Cooperative Extension, 3800 Cornucopia Way, Suite A, Modesto 95358
}

\section{ABSTRACT}

Whole tomato seeds, a novel by-product feedstuff, were fed to lactating Holstein cows to determine the nutritive value of whole tomato seeds by replacing whole cottonseed in the total mixed ration. Four primiparous and 4 multiparous Holstein cows were used in a $4 \times 4$ Latin square design and fed 1 of 4 total mixed rations. Whole tomato seeds replaced whole cottonseed on a weight-to-weight basis for lipid. The proportion of whole tomato seeds to whole cottonseed in the diets were 100:0, 50:50, 25:75, and 0:100 on a lipid basis. Thus, tomato seeds were 4.0, 2.4, 1.1, and $0 \%$ of the ration dry matter, respectively. Milk yield and the concentrations and yields of protein, lactose, and solids-not-fat did not differ for the effect of diet. However, milk fat concentration decreased and milk fat yield tended to decrease as whole tomato seeds replaced whole cottonseed. Intakes of dry matter, lipid, and crude protein did not differ. Whole-tract apparent digestibility of dry matter and ash-free neutral detergent fiber did not differ, but digestibility of total fatty acids and crude protein decreased with increasing proportion of whole tomato seeds. Urea concentration in milk and plasma both decreased with increasing whole tomato seeds. Fecal concentration of linoleic and $\alpha$-linolenic acids increased with increasing whole tomato seeds, suggesting that seeds were passing out of the digestive tract undigested. The concentrations of $\mathrm{C} 18: 2 \mathrm{n}-6$ and C18:3n-3 in milk fat had small increases, but their yields were not different, suggesting that only a small amount of whole-tomato-seed lipid might have been digested postruminally. Amounts of trans C18:1 fatty acids in milk fat were higher with increasing whole cottonseed, which might suggest a shift in rumen biohydrogenation pathways. At the level of feeding used in the current study, whole tomato seeds replaced whole cottonseed in the diet of lactating dairy cows without a change in production.

Key words: tomato seed, by-product

Received November 17, 2014.

Accepted March 6, 2015.

${ }^{1}$ Corresponding author: ejdepeters@ucdavis.edu

\section{INTRODUCTION}

In 2011, California produced $96 \%$ of processing tomatoes in the United States (10.8 million tonnes) on 250,000 acres with a total farm value of $\$ 887$ million (California Department of Food and Agriculture, 2012). Processing tomatoes are used to make human-edible products including sauce, juice, soup, and paste. Tomato products are consumed because of their convenience of use as a preserved food but also because of attributed health benefits associated with lycopene, a phytonutrient carotenoid, as well as other antioxidants found in tomatoes that may possess anticarcinogenic properties (Schieber et al., 2001; Ellinger et al., 2006). Tomato pomace is a by-product of producing tomato paste, juice, and sauce. Tomato pomace is a mixture of seed, skin, and pulp that is fed to cattle. A new proprietary process for tomatoes captures more skin and pulp in the human-edible portion and creates a byproduct portion that is predominantly tomato seeds. No information exists in the literature on the feeding value of whole tomato seeds (WTS) to lactating cows.

During commercial processing of tomatoes for the production of paste and sauce, between 3 and $30 \%$ of the fresh tomato (wet-weight basis) is lost as a humaninedible waste product depending on the product produced (Schieber et al., 2001; King and Zeidler, 2004). Whole tomato seeds are approximately $10 \%$ of the tomato and $60 \%$ of the total waste product (Schieber et al., 2001). Peel and seed by-products are estimated to account for between 20 and $50 \%$ of the initial weight of the raw tomatoes (Knoblich et al., 2005), and this byproduct is often called tomato pomace and consists of seed, skin, and pulp (Del Valle et al., 2006). Tomato byproduct contained $3.34 \%$ moisture, $11.29 \%$ fat, $16.36 \%$ protein, $14.35 \%$ total sugars, $7.83 \%$ pectins, $51.32 \%$ fiber, and $3.85 \%$ ash, and the tomato seeds contain $24.76 \%$ protein and $21.87 \%$ total fat (Del Valle et al., 2007). Del Valle et al. (2006) summarized data from the literature to report that tomato pomace varied considerably in composition with 15 to $23 \%$ total protein, 5 to $20 \%$ total fat, 4 to $6 \%$ ash, and 25 to $51 \%$ fiber. Unused fractions of processing tomatoes are a concern for the tomato industry because the cost of their dis- 
posal can be high, and the waste by-products can be an environmental issue. One solution for tomato pomace is its use as a feedstuff for livestock. However, based on published composition data (Del Valle et al., 2006, 2007), the chemical composition of tomato by-products has considerable variability. To minimize changes in the nutrient composition of rations fed to livestock, the chemical composition of tomato by-products should be monitored.

Tomato pomace has been successfully fed to both nonruminant and ruminant animals. King and Zeidler (2004) included ground tomato pomace at $30 \%$ of the diet DM fed to broiler chicks as a source of $\alpha$-tocopherol to minimize lipid deterioration in the meat. Tomato pomace has been fed to sheep (Hinman et al., 1978; Fondevila et al., 1994; Ziaei and Molaei, 2010; Abbeddou et al., 2011a,b) and beef cattle (Chumpawadee and Pimpa, 2009; Yuangklang et al., 2010a,b). Tomato pomace was fed to growing lambs at $20 \%$ of the diet, and growth performance was similar to that in lambs fed soybean protein (Fondevila et al., 1994). It was noted in sheep trials that RUP from tomato pomace protein might not be readily available to sheep (Fondevila et al., 1994). Hinman et al. (1978) fed tomato pomace at $0,26,48,77.5$, or $100 \%$ of the diet to sheep and showed that tomato pomace in a diet decreased CP digestibility when fed alone rather than as a component of a forage mix. Weiss et al. (1997) fed wet tomato pomace that was ensiled with corn forage at 0 or $12 \%$ of the DM to lactating dairy cattle with no effect on milk yield and composition; DMI; apparent digestibility of DM, NDF, and N; and $\mathrm{N}$ balance.

Retaining a higher amount of tomato skin and pulp in the human-edible tomato-concentrate product increased its nutritional value (i.e., increased protein and fat) and enhanced technological properties (i.e., thicker consistency) while reducing the amount of tomato pomace (Del Valle et al., 2003). In the present study, we evaluated a new proprietary technology to increase retention of pulp and skin peel in the human-edible tomato concentrate. This process yielded a humaninedible by-product that was high in WTS. Tomato seeds are high in protein (35\%) and lipid (25\%) content (Schieber et al., 2001). However, as in tomato pomace, Latlief and Knorr (1983) reported variability in the composition of WTS with 22.9 to $33.9 \%$ CP, 20.5 to $29.6 \%$ crude fat, 15.5 to $21.7 \%$ crude fiber, and 3.9 to $9.6 \%$ ash. Tomato-seed meal contained between 25.5 and 26.2\% ether extract (Turakhozhaev et al., 1979; Yaseen et al., 1991) and from 22.9 to $46.75 \%$ protein (Turakhozhaev et al., 1979; Brodowski and Geisman, 1980; Morad et al., 1980; Yaseen et al., 1991). No published research exists on the nutritive value of WTS for lactating dairy cows.
The objective was to determine the nutritive value of WTS in the diet of primiparous and multiparous lactating Holstein cows to support milk synthesis. The null hypothesis was that the nutritive value of WTS was similar to whole cottonseed (WCS) for lactating cows regardless of parity.

\section{MATERIALS AND METHODS}

\section{Animals, Diets, Treatments, and Experimental Design}

The WTS were delivered wet and were sun dried for approximately $48 \mathrm{~h}$ and hand screened of excess fibrous material (i.e., pulp and skin) using a screen with a 0.5$\mathrm{cm}$ opening. Although WTS are fed wet on commercial dairy farms, the WTS were sun dried to prevent spoilage. Drying and hand screening allowed the creation of a more consistent WTS so that WTS from different days of processing could be mixed.

Rations were formulated to contain 4\% lipid (DM basis) in the TMR. The $4 \%$ lipid in the TMR was predominately from a combination of WCS and WTS with WTS replacing WCS 1:1 on an equivalent lipid basis. The ratios of WTS to WCS in the 4 TMR treatments were (1) tomato-seed TMR with 100\% WTS:0\% WCS; (2) high-tomato-seed TMR with 44\% WTS:56\% WCS; (3) low-tomato-seed TMR with 19\% WTS:81\% WCS; and (4) cottonseed TMR with 0\% WTS:100\% WCS to achieve an equivalent lipid basis of 100:0, 50:50, 25:75, and 0:100 (WTS:WCS lipid).

Eight lactating Holstein cows between 60 and 100 DIM at the beginning of the study were used. Cows were subdivided into 2 groups according to parity with 4 primiparous and 4 multiparous cows, with cows blocked based on parity. At the beginning of the study the primiparous cows averaged $585 \mathrm{~kg}$ of $\mathrm{BW}(\mathrm{SD} \pm 21$ $\mathrm{kg}$ ), 99 DIM ( $\mathrm{SD} \pm 16 \mathrm{~d}$ ), and $40 \mathrm{~kg} / \mathrm{d}$ of milk (SD \pm 4 $\mathrm{kg})$. Multiparous cows averaged $713 \mathrm{~kg}$ of $\mathrm{BW}(\mathrm{SD} \pm 38$ $\mathrm{kg}$ ), $90 \mathrm{DIM}(\mathrm{SD} \pm 7 \mathrm{~d}$ ), and $53 \mathrm{~kg} / \mathrm{d}$ of actual milk ( $\mathrm{SD} \pm 6 \mathrm{~kg}$ ). Each period was $21 \mathrm{~d}$, with the first $14 \mathrm{~d}$ for feed acclimation and the last $7 \mathrm{~d}$ of each period for sample collection. Animal-care practices were approved by the Institutional Animal Care and Use Committee of the University of California at Davis.

Cows were fed a TMR in a replicated $4 \times 4$ Latin square design with WTS replacing whole linted cottonseed (WCS) 1:1 (wt/wt) on a lipid basis. The ingredient compositions for the 4 TMR are shown in Table 1. The alfalfa hay and the oat hay were first passed through a bale slicer (Montano Inc., Merced, CA) to minimize differences in forage particle length from batch to batch and then put into a horizontal feed mixer wagon with a scale (Laird Welding and Manufacturing Co., Merced, 
Table 1. Ingredient composition (\% of DM) of TMR (100\% DM basis)

\begin{tabular}{lrrrr}
\hline Ingredient & TS $^{1}$ & HTS $^{2}$ & LTS $^{3}$ & CS $^{4}$ \\
\hline Alfalfa hay, sliced & 37.5 & 37.0 & 36.8 & 36.5 \\
Corn, steam flaked & 29.6 & 29.1 & 28.9 & 28.7 \\
Soybean hull pellets & 8.7 & 8.5 & 8.5 & 8.4 \\
Almond hulls & 7.8 & 7.7 & 7.7 & 7.6 \\
Cottonseed, whole & 0.0 & 3.0 & 4.8 & 6.7 \\
Canola meal & 6.0 & 6.0 & 6.0 & 5.9 \\
Oat hay, sliced & 4.2 & 4.1 & 4.0 & 4.0 \\
Tomato seed & 4.0 & 2.4 & 1.1 & 0.0 \\
Molasses, cane & 0.7 & 0.7 & 0.7 & 0.7 \\
Sodium bicarbonate & 0.7 & 0.7 & 0.7 & 0.7 \\
Oyster shell & 0.3 & 0.3 & 0.3 & 0.3 \\
Trace mineral & 0.2 & 0.2 & 0.2 & 0.2 \\
Salt & 0.2 & 0.2 & 0.2 & 0.2 \\
Magnesium oxide & 0.1 & 0.1 & 0.1 & 0.1 \\
\hline
\end{tabular}

${ }^{1} \mathrm{TS}=$ tomato seed as $100 \%$ of the lipid supplement in TMR.

${ }^{2} \mathrm{HTS}=50 \%$ tomato seed: $50 \%$ whole cottonseed as lipid supplement ratio in TMR.

${ }^{3} \mathrm{LTS}=25 \%$ tomato seed: $75 \%$ whole cottonseed as lipid supplement ratio in TMR.

${ }^{4} \mathrm{CS}=$ whole cottonseed fed as $100 \%$ of the lipid supplement in TMR.

${ }^{5}$ Trace mineral: $9.05 \mathrm{~g}$ of calcium/100 g of DM, $0.02 \mathrm{~g}$ of phosphorous $/ 100 \mathrm{~g}$ of DM, $0.3 \mathrm{~g}$ of potassium/100 $\mathrm{g}$ of DM, $6.73 \mathrm{~g}$ of chloride/100 $\mathrm{g}$ of $\mathrm{DM}, 6.02 \mathrm{~g}$ of magnesium/100 $\mathrm{g}$ of DM, $16.48 \mathrm{~g}$ of sodium/100 $\mathrm{g}$ of DM, $0.15 \mathrm{~g}$ of sulfur/100 $\mathrm{g}$ of DM, $11.2 \mathrm{~g}$ of salt/100 $\mathrm{g}$ of DM, $830 \mathrm{mg}$ of iron/ $\mathrm{kg}$ of DM, 1,196 $\mathrm{mg}$ of manganese $/ \mathrm{kg}$ of DM, $404.6 \mathrm{mg}$ of copper $/ \mathrm{kg}$ of DM, $16.34 \mathrm{mg}$ of selenium $/ \mathrm{kg}$ of DM, 16.34 $\mathrm{mg}$ of zinc $/ \mathrm{kg}$ of DM, $77.82 \mathrm{mg}$ of iodine $/ \mathrm{kg}$ of DM, $77.8 \mathrm{mg}$ of cobalt/ $\mathrm{kg}$ of DM, $43.8 \mathrm{mg}$ of biotin $/ \mathrm{kg}$ of DM, $365 \mathrm{kIU}$ of vitamin $\mathrm{A} / \mathrm{kg}$ of DM, $73 \mathrm{kIU}$ of vitamin D/kg of DM, 2,434 kIU of vitamin $\mathrm{E} / \mathrm{kg}$ of DM, 389.4 mg of Rumensin (Elanco, Greenfield, IN) $/ \mathrm{kg}$ of DM, and $0.88 \mathrm{~g}$ of Zinpro 100 (Zinpro Corporation, Eden Prairie, MN).

CA) with the other TMR ingredients. The WTS and WCS were weighed separately on a top-loader balance and were added as a final component to the TMR in the mixer wagon.

Cows were housed in an open corral with freestalls bedded with sand and with free access to water. Calan Broadbent feeding doors (American Calan Inc., Northwood, NH) were used to feed cows individually ad libitum at approximately 0800 and $2000 \mathrm{~h}$ each day during the first $11 \mathrm{~d}$ of each period. Body weights were recorded 2 times per week after morning milkings throughout the study. Feed offered and feed refused for each feeding were weighed and recorded.

Samples of each diet were collected weekly during wk 1 and 2 of each period and were analyzed for moisture content. During the 7-d sample collection period, feed was reduced to $97 \%$ of that fed in the previous 3 -d freechoice feeding period to ensure no feed refusals because lignin was used as an internal digestibility marker and there can be no feed refusals using an indicator ratio method. Apparent digestibility (DM basis) for each diet component was determined according to Schneider and Flatt (1975).

Two samples of each TMR were taken during d 15 to 19 of the collection period. The daily samples of each
TMR were composited to create 2 separate samples for each TMR, and samples were stored at room temperature $\left(25^{\circ} \mathrm{C}\right)$ in sealed plastic bags. One sample of each TMR was analyzed for moisture content in a $100^{\circ} \mathrm{C}$ forced-air oven for $15 \mathrm{~h}$. The second composite sample of each TMR was air dried at room temperature $\left(25^{\circ} \mathrm{C}\right)$ for 72 to $96 \mathrm{~h}$. The entire sample of TMR was then ground through a 1-cm screen using a hammermill (model no. WB6A, Montgomery Ward, Madison, WI) to minimize errors associated with subsampling a TMR. The coarsely ground sample was then ground through a 1-mm screen using a Wiley Mill (Arthur A. Thomas, Philadelphia, PA). The ground samples were stored in sealed plastic containers at room temperature $\left(25^{\circ} \mathrm{C}\right)$ for later analysis.

Fecal grab samples were collected during the samplecollection period twice daily (a.m. and p.m.) for $5 \mathrm{~d}$ at each milking. Fecal samples were composited for each cow and stored frozen in a sealed plastic bag $\left(-20^{\circ} \mathrm{C}\right)$ for 1 wk. Fecal samples were thawed at room temperature, mixed by hand, placed in aluminum pans, and dried in a forced-air oven $\left(55^{\circ} \mathrm{C}\right)$. Fecal samples were ground through a 1-mm screen using a Wiley Mill (Arthur A. Thomas). Dried ground samples were stored in sealed plastic containers at room temperature for later analysis.

Cows were milked twice daily at 0730 and $1930 \mathrm{~h}$. Milk weights were recorded at each milking using Westfalia milk meters (GEA Farm Technologies, Bonen, Germany). On d 18 to 20 of each period, milk samples were collected and pooled from each cow from consecutive evening and morning milkings using Westfalia individual proportional milk samplers and milk meters to create 2 daily milk samples for each cow. Following the a.m. milking, milk samples were transported to the laboratory and warmed to $40^{\circ} \mathrm{C}$ in a water bath, and the samples were mixed to create a composite. Daily milk sample composites were d 18 p.m. + d 19 a.m. as d 1 and d 19 p.m. + d 20 a.m. as d 2. Milk samples were analyzed for total protein, fat, SNF, and lactose content using the Bentley 150 Infrared Milk Analysis (Bentley Instruments, Chaska, MN). The milk analyzer was calibrated with milk standards provided by the State of California based on wet chemistry. Milk urea nitrogen was determined using an autoanalyzer, and FA composition of milk lipids was determined via gas chromatography (Hewlett-Packard model 5890, equipped with flame ionization detector, and model 7673A auto injector, Palo Alto, CA). Milk samples were shipped under refrigeration $\left(5^{\circ} \mathrm{C}\right)$ to Silliker Labs (Modesto, CA) for SCC via the direct microscopic method.

Blood samples were collected on d 20 of each period from a coccygeal vessel from all cows before feeding (i.e., $\mathrm{h}=0$ ), and at 2 and $4 \mathrm{~h}$ after the morning feed- 
ing. Blood was collected into $10-\mathrm{mL}$ Vacutainer tubes with sodium heparin (BD Vacutainer, BD, Franklin Lakes, NJ). Within 15 min of collection, blood tubes were centrifuged (IEC Centra CL3 Centrifuge, Thermo Electron Corp., Milford, MA) at 1,200 $\times g$ for $15 \mathrm{~min}$ at room temperature to isolate plasma. Plasma was retained, placed into 13-mL plastic test tubes (Sarstedt, Aktiengesellschaft Company, Nümbrecht, Germany), and stored at $-20^{\circ} \mathrm{C}$ until analysis for plasma urea nitrogen (PUN).

\section{Analytical Procedures}

Composite ground samples of TMR and feces were analyzed in duplicate for DM (AOAC International, 1995; method 925.40), total N (AOAC International, 1995; method 984.13) with percentage CP calculated as the percentage of $\mathrm{N} \times 6.25$, NDF (Van Soest and Robertson, 1991), and ADF, cellulose, and lignin (Robertson and Van Soest, 1981). Lipid content of samples was determined by gas-liquid chromatography (Palmquist and Jenkins, 2003).

Pooled milk samples (p.m. + a.m. composite) from each sample day were analyzed for fat, protein, lactose, and SNF (AOAC International, 1995; method 972.16) with an infrared analyzer (Bentley 150) and for MUN by Technicon Autoanalyzer method N-10a (Marsh et al., 1957). Plasma urea nitrogen was also determined according to Marsh et al. (1957).

A 10-mL aliquot of milk was used for the analysis of the FA composition of lipids (DePeters et al., 2001). Methyl esters of FA were separated and quantified by gas-liquid chromatography (Hewlett-Packard model 5890 , equipped with flame ionization detector, and model 7673A auto injector) with a Supelco SP-2560 fused silica capillary column $(100 \mathrm{~m} \times 0.25 \mathrm{~mm}$ i.d., 0.20- $\mu \mathrm{m}$ film thickness; Supelco Inc., Bellefonte, PA). The carrier gas was $\mathrm{H}_{2}$ with a $0.77 \mathrm{~mL} / \mathrm{min}$ flow rate (linear flow rate, $27 \mathrm{~cm} / \mathrm{s}$ ), $220^{\circ} \mathrm{C}$ injector temperature, and 1:88 split ratio, and the temperature was programmed, with an initial temperature of $70^{\circ} \mathrm{C}$ for 10 min followed by a programmed increase to $175^{\circ} \mathrm{C}$ at $20^{\circ} / \mathrm{min}$ for $29 \mathrm{~min}$, and finally to $225^{\circ} \mathrm{C}$ at $5^{\circ} / \mathrm{min}$ for 12 min. Fatty acid peaks were identified by comparison with a standard mixture containing known quantities of FA.

\section{Statistical Analyses}

Milk yield and composition, intake of chemical constituents, and whole-tract apparent digestibility were analyzed using Proc MIXED of SAS (SAS Institute, 1999) according to the model

$$
Y_{i j k l}=\mu+A_{i}+c_{j(i)}+P_{k}+T_{l}+A T_{i l}+P T_{k l}+E_{i j k l},
$$

where $Y_{i j k l}=$ dependent variable measured for the $i$ th parity, the $j$ th cow within the $i$ th parity, during the $k$ th period, and the $l$ th treatment; $\mu=$ overall constant; $A_{i}$ $=$ fixed effect of the $i$ th parity, $i=1,2 ; c_{j(i)}=$ random effect of the $j$ th cow within the $i$ th parity, $j=1,2,3,4$; $P_{k}=$ fixed effect of the $k$ th period, $k=1,2,3,4 ; T_{l}=$ fixed effect of the lth treatment, $l=1,2,3,4 ; A T_{i l}=$ interaction term of the $i$ th parity with the $l$ th treatment; $P T_{k l}=$ interaction term of the $k$ th period with the $l$ th treatment; and $E_{i j k l}=$ error term $\sim N\left(0, \sigma_{e}^{2}\right)$. Linear and quadratic effects of treatments were estimated by orthogonal contrast (Littell et al., 1996) and adjusted for unequal spacing using the orpol() function in PROC IML version 9.1 (SAS Institute Inc., 2011). A $P$-value of $\leq 0.05$ was considered significant, and $P$-value $>0.05$ and $\leq 0.10$ was considered a trend.

Plasma urea $\mathrm{N}$ measurements were analyzed using a similar model but time was added as a fixed effect, and interactions for time $\times$ parity and time $\times$ period were added. These 2 time interactions had $P$-values $>0.50$ and were not reported.

\section{RESULTS}

\section{Ingredient and Diet Compositions}

Chemical compositions (Table 2) of the TMR were similar and reflect differences in ingredient composition. Whole tomato seeds contained greater total FA and CP and less fiber compared with WCS (Table 3). Ether extract content of WTS and WCS was similar even though total FA concentration differed. Whole tomato seeds contained more C18:0, cis-9 and cis-10 C18:1, C18:2n-6, and C18:3n-3 and less C16:0 than WCS on a DM basis (Table 4). The concentration of C16:0 was lower and concentration of C18:3n-3 was higher in WTS than WCS lipid (Table 5). The FA composition of the TMR reflected the source of dietary lipid from WTS or WCS. Although, because WTS and WCS were substituted on a lipid-for-lipid basis, other ingredients changed slightly, so these ingredient changes also are reflected in the FA content of the TMR.

\section{Milk Production}

Milk yield (Table 6) was not different in response to replacing dietary lipid from WCS with WTS. Milk yield also did not differ between primiparous and multiparous cows. Primiparous cows averaged $41.5 \mathrm{~kg}$ of milk/d, and multiparous cows averaged $44.5 \mathrm{~kg}$ of milk/d. Yields of (4\%) FCM and milk energy increased significantly $(P<0.04)$ as the proportion of WTS to 
Table 2. Chemical composition (\% of DM) of $\mathrm{TMR}^{1}$

\begin{tabular}{lrrrr}
\hline Item & \multicolumn{1}{c}{ TS $^{2}$} & \multicolumn{1}{c}{ HTS $^{3}$} & LTS $^{4}$ & CS $^{5}$ \\
\hline Protein & $16.53(0.47)$ & $16.85(1.42)$ & $16.66(0.86)$ & $16.55(0.82)$ \\
FA & $3.12(0.40)$ & $3.45(0.51)$ & $3.37(0.06)$ & $3.29(0.42)$ \\
Cellulose & $17.03(0.88)$ & $18.32(2.09)$ & $18.11(0.26)$ & $17.5(0.83)$ \\
Lignin & $4.63(0.26)$ & $4.89(0.77)$ & $4.7(0.31)$ & $4.67(0.28)$ \\
Ash-free ADF & $21.70(0.95)$ & $23.26(2.65)$ & $22.8(0.56)$ & $22.16(1.16)$ \\
Ash-free NDF & $40.01(1.86)$ & $44.25(8.04)$ & $40.32(5.14)$ & $37.92(1.54)$ \\
Ash & $7.14(0.19)$ & $7.08(0.37)$ & $7.42(0.40)$ & $7.17(0.60)$ \\
\hline
\end{tabular}

${ }^{1}$ Standard deviation for 4 diet samples given in parentheses.

${ }^{2} \mathrm{TS}=$ tomato seed as $100 \%$ of the lipid supplement in TMR.

${ }^{3} \mathrm{HTS}=50 \%$ tomato seed:50\% whole cottonseed as lipid supplement ratio in TMR

${ }^{4} \mathrm{LTS}=25 \%$ tomato seed: $75 \%$ whole cottonseed as lipid supplement ratio in TMR.

${ }^{5} \mathrm{CS}=$ whole cottonseed fed as $100 \%$ of the lipid supplement in TMR.

WCS in the diet decreased. Milk fat concentration decreased linearly $(P<0.01)$ as the proportion of WTS to WCS increased. Milk fat yield tended $(P<0.08)$ to decrease when WTS lipid replaced WCS lipid in the diet. Concentrations and yields of protein, lactose, and SNF did not differ for dietary treatment. However, MUN concentration decreased linearly $(P<0.01)$ when WTS lipid replaced WCS lipid in the diet. Finally, SCC did not differ with dietary treatment or parity.

\section{Intake of Chemical Constituents and BW}

Intakes $(\mathrm{kg} / \mathrm{d})$ of $\mathrm{DM}, \mathrm{CP}$, total FA, C18:2, and C18:3 (Table 7) did not differ for dietary treatment. Intake of ash-free NDF was highest for high-tomatoseed cows $(P<0.03$; quadratic $)$, which reflected the higher TMR concentration of ash-free NDF. Intakes of DM $(P<0.08)$, CP $(P<0.06)$, ash-free NDF $(P<$ $0.07)$, ash-free $\operatorname{ADF}(P<0.06)$, cellulose $(P<0.04)$, total FA $(P<0.09), \mathrm{C} 18: 2(P<0.09)$, and $\mathrm{C} 18: 3(P$ $<0.02)$ were higher for multiparous than primiparous cows as expected. Body weight of cows did not differ by treatment.

\section{Whole-Tract Apparent Digestibility}

Whole-tract apparent digestibility of DM, ash-free ADF, cellulose, and intake energy were not affected by dietary treatment (Table 8). Apparent digestibility of

Table 3. Chemical composition $(\mathrm{g} / 100 \mathrm{~g}$ of $\mathrm{DM})$ of whole tomato seeds (WTS) and whole cottonseed (WCS)

\begin{tabular}{lcc}
\hline Item & WTS & WCS \\
\hline FA & 28.5 & 20.1 \\
CP & 30.5 & 23.5 \\
Ether extract & 20.0 & 20.3 \\
NDF & 37.6 & 50.3 \\
ADF & 21.5 & 30.8 \\
Ash & 3.8 & 3.8 \\
\hline
\end{tabular}

CP decreased linearly $(P<0.04)$ as the proportion of WTS to WCS increased. Apparent digestibility of total FA decreased linearly $(P<0.0001)$ as the proportion of WTS to WCS in the diet increased. Similar to total FA, the apparent digestibility of $\mathrm{C} 18: 2$ and C18:3n-3 decreased linearly $(P<0.0001)$ as the proportion of WTS to WCS in the diet increased. Whole-tract apparent digestibility did not differ by parity for any parameter measured.

\section{PUN}

Concentration of PUN was affected by a parity-bytreatment interaction $(P<0.008)$ because PUN decreased more with multiparous compared with primiparous cows as more WTS was substituted for WCS in the diet (Table 9). Plasma urea $\mathrm{N}$ changed (not shown) with time $(P<0.03)$, where PUN changed from 13.4 to 14.3 to $14.2 \mathrm{mg} / 100 \mathrm{~mL}$ for times 0,2 , and 4 , respectively. The period-by-parity interaction $(P>0.07)$ and treatment-by-time interaction $(P>0.09)$ were not considered important and thus were not included in Table 9.

\section{Concentration and Yield of Milk FA}

Concentrations of $\mathrm{C} 11: 0(P<0.04), \mathrm{C} 12: 0(P<$ 0.01), C13:0 $(P<0.005), \mathrm{C} 14: 0(P<0.006)$, cis $\mathrm{C} 14: 1$

Table 4. Fatty acid composition ( $\mathrm{g}$ of FA/100 $\mathrm{g}$ of DM) of whole tomato seeds (WTS) and whole cottonseed (WCS)

\begin{tabular}{lrc}
\hline FA & WTS & WCS \\
\hline C16:0 & 3.81 & 4.46 \\
trans C17:1 & 0.15 & 0.00 \\
C18:0 & 1.28 & 0.50 \\
cis-9 and cis-10 C18:1 & 5.60 & 3.20 \\
C18:2n-6 & 15.79 & 10.86 \\
C18:3n-3 & 0.63 & 0.04 \\
Unknown & 1.22 & 1.04 \\
Total & 28.48 & 20.12 \\
\hline
\end{tabular}


Table 5. Fatty acid composition ( $\mathrm{g}$ of FA/100 g of FA) of whole tomato seeds (WTS) and whole cottonseed (WCS)

\begin{tabular}{lrr}
\hline FA & WTS & WCS \\
\hline C14:0 & 0.12 & 0.87 \\
C16:0 & 13.38 & 22.18 \\
cis C16:1 & 0.25 & 0.54 \\
trans C17:1 & 0.53 & 0.00 \\
C18:0 & 4.48 & 2.46 \\
cis-9 and cis-10 C18:1 & 19.65 & 15.90 \\
cis-11 C18:1 & 0.96 & 0.83 \\
C18:2n-6 & 55.45 & 53.98 \\
C20:0 & 0.34 & 0.27 \\
C18:3n-3 & 2.21 & 0.22 \\
Unknown & 2.63 & 2.74 \\
\hline
\end{tabular}

$(P<0.0011), \mathrm{C} 15: 0(P<0.001), \mathrm{C} 16: 0(P<0.07)$, cis C16:1 $(P<0.01), \mathrm{C} 17: 0(P<0.0015)$, trans $\mathrm{C} 17: 1(P<$ $0.0011)$, cis-11 18:1 $(P<0.05)$, C18:3n-3 $(P<0.007)$, and cis-9,trans-11 C18:2 $(P<0.02)$ increased linearly as the proportion of dietary lipid from WTS increased (Table 10). Concentrations of C18:0 $(P<0.0012)$, trans-6 and trans-8 C18:1 $(P<0.06)$, trans-12 C18:1 $(P<0.001)$, trans-13 and trans-14 C18:1 $(P<0.001)$, and trans-16 C18:1 $(P<0.0006)$ decreased linearly as the proportion of dietary lipid from WTS increased. Concentrations of trans-10 C18:1 and trans-11 C18:1, intermediates of rumen biohydrogenation of cis-9 cis-12 C18:2, were not affected by dietary treatment.

Fatty acid yield (Table 11) showed significant linear decreases as dietary lipid from WTS increased for C18:0, trans- 6 and trans-8 C18:1, trans-12 C18:1, trans-13 and trans-14 C18:1, cis-9 and cis-10 C18:1, cis-12 C18:1, trans-16 C18:1, C20, and C18:3n-6 and showed a trend for trans-10 C18:1. Significant linear increases were found in FA yields for cis C14:1, trans $\mathrm{C} 17: 1$, and cis9,trans-11 C18:2 as WTS lipid increased in the diets. Fatty acid yield showed significant quadratic changes for C11:0, C13:0, C15:0, cis C16:1, trans-10 C18:1, trans-13 and trans-14 C18:1, and cis-12 C18:1.

\section{Fecal FA Data}

Fecal concentration of C18:2n-6 and C18:3n-3 increased linearly $(P<0.0001)$ as the proportion of WTS to WCS increased in the TMR (Table 12). Parity had no effect on fecal concentration of these selected FA.

\section{DISCUSSION}

Development of new processing technology for tomatoes to retain a higher amount of the pulp and skin in the human-edible portion results in a waste by-product that is composed predominately of WTS in a wet form. No information exists on the nutritive value of WTS for lactating dairy cows. Whole tomato seeds are small in size, which could affect rumen passage rate and whole-tract digestibility. Tomato seeds were flat and not perfectly round. Two measurements using a digital caliper were the thickness of the seed and the widest part of the seed. The means and standard deviations of 20 seeds were $0.59( \pm 0.113) \mathrm{mm}$ for thickness and $2.83( \pm 0.545) \mathrm{mm}$ for width. In the current study, the WTS were air dried before feeding to allow for storage and to create a uniform by-product to feed. Drying likely affects the nutrient utilization of WTS, so future research should evaluate WTS that are fed to lactating dairy cows in the wet form because the hydration rate and density of wet WTS in the rumen might be different from WTS fed in the dry form. Feeding wet WTS is more economical than drying; however, in the present study drying decreased the likelihood of spoilage and made it easier to control experimental conditions.

In the current study, dietary lipid from WTS replaced lipid from WCS on a FA basis. Tomato seeds used in the current study were high in lipid (28.5 g of FA/100 $\mathrm{g}$ of DM) content. In our laboratory work, ether extraction (EE) with diethyl ether consistently estimated lipid content to be approximately $20 \%$. Similar results were obtained for EE from one commercial laboratory. Acid hydrolysis along with EE estimated lipid content to be between 24 and $27 \%$. Although not reported here, FA were found in the EE residue upon analysis to account for the lipid not extracted by EE. This analytical issue might explain the large range in crude fat, 20.5 to $29.6 \%$, reported previously by Latlief and Knorr (1983) for WTS. Thus, FA were used for the lipid estimate of both WTS and WCS. Whole cottonseed contained $20.1 \mathrm{~g}$ of FA/100 $\mathrm{g}$ of DM lipid. Because the WTS were higher in lipid content than WCS, the ingredient composition of the diets differed slightly (Table 1).

Milk yield was not affected by WTS substituting for WCS in the diet (Table 6). The concentration and yield of protein, lactose, and SNF did not differ with dietary treatment. However, the concentration $(P<0.01)$ and yield $(P<0.08)$ of milk fat decreased (linear effect) as the proportion of WTS to WCS increased. Weiss et al. (1997) showed no differences in milk yield and component concentration for protein and fat when tomato pomace was fed ensiled with corn grain.

Intake of DM, CP, and total FA did not differ for diet (Table 7). Intake of ash-free NDF differed, and these intake differences reflect diet concentration of ash-free NDF and were likely not due to any inherent difference between WTS and WCS but instead how the diet ingredients were formulated. In contrast to the current study, when dried tomato pomace was fed to growing beef steers at varying levels including $3.2,8.0$, and $11.2 \%$ of DM, DMI decreased significantly as dried tomato pomace increased in the ration, which 
Table 6. Milk production and composition by lactating primiparous (P) and multiparous (M) dairy cows fed diets with varying amounts of tomato seed and whole cottonseed

\begin{tabular}{|c|c|c|c|c|c|c|c|c|c|c|c|c|}
\hline \multirow[b]{2}{*}{ Item } & \multirow[b]{2}{*}{ Parity } & \multicolumn{4}{|c|}{ Treatment $^{1}$} & \multirow[b]{2}{*}{ SEM } & \multirow[b]{2}{*}{$\mu^{2}$} & \multicolumn{5}{|c|}{$P$-value ${ }^{3}$} \\
\hline & & TS & HTS & LTS & CS & & & $\mathrm{TE}$ & $\mathrm{PE}$ & $\mathrm{PE} \times \mathrm{TE}$ & $\mathrm{L}$ & $\mathrm{Q}$ \\
\hline \multirow[t]{2}{*}{$\operatorname{Milk}(\mathrm{kg} / \mathrm{d})$} & $\mathrm{P}$ & 41.70 & 41.00 & 41.30 & 41.90 & 1.65 & 42.98 & 0.89 & 0.28 & 0.87 & 0.58 & 0.59 \\
\hline & M & 44.00 & 44.50 & 44.70 & 44.70 & & & & & & & \\
\hline \multirow{2}{*}{$4 \%$ FCM $(\mathrm{kg} / \mathrm{d})$} & $\mathrm{P}$ & 38.80 & 37.60 & 39.50 & 41.40 & 1.39 & 39.43 & 0.06 & 0.85 & 0.40 & 0.04 & 0.11 \\
\hline & M & 39.00 & 38.00 & 41.30 & 40.00 & & & & & & & \\
\hline \multirow[t]{2}{*}{$\mathrm{NE}_{\mathrm{L}}(\mathrm{Mcal})$} & $\mathrm{P}$ & 29.47 & 28.53 & 30.06 & 31.56 & 1.04 & 30.09 & 0.06 & 0.72 & 0.35 & 0.04 & 0.11 \\
\hline & M & 29.77 & 29.37 & 31.40 & 30.52 & & & & & & & \\
\hline \multirow[t]{2}{*}{ Fat $(\mathrm{g} / \mathrm{kg})$} & $\mathrm{P}$ & 34.40 & 35.50 & 36.60 & 35.10 & 1.51 & 34.91 & 0.007 & 0.85 & 0.05 & 0.01 & 0.63 \\
\hline & M & 33.90 & 31.90 & 36.20 & 35.70 & & & & & & & \\
\hline \multirow{2}{*}{ Fat $(\mathrm{kg} / \mathrm{d})$} & $\mathrm{P}$ & 1.43 & 1.45 & 1.51 & 1.47 & 0.06 & 1.480 & 0.08 & 0.82 & 0.44 & 0.08 & 0.82 \\
\hline & M & 1.46 & 1.40 & 1.58 & 1.55 & & & & & & & \\
\hline \multirow[t]{2}{*}{ Protein $(\mathrm{g} / \mathrm{kg})$} & $\mathrm{P}$ & 33.20 & 33.10 & 33.20 & 33.40 & 0.13 & 33.30 & 0.93 & 0.99 & 0.57 & 0.59 & 0.85 \\
\hline & M & 33.20 & 33.40 & 33.40 & 33.10 & & & & & & & \\
\hline \multirow[t]{2}{*}{ Protein $(\mathrm{kg} / \mathrm{d})$} & $\mathrm{P}$ & 1.38 & 1.35 & 1.37 & 1.40 & 0.05 & 1.42 & 0.89 & 0.08 & 0.75 & 0.57 & 0.62 \\
\hline & M & 1.45 & 1.48 & 1.47 & 1.47 & & & & & & & \\
\hline \multirow[t]{2}{*}{ Lactose $(\mathrm{g} / \mathrm{kg})$} & $\mathrm{P}$ & 51.20 & 51.10 & 51.00 & 51.40 & 0.86 & 50.40 & 0.45 & 0.50 & 0.89 & 0.44 & 0.16 \\
\hline & $\mathrm{M}$ & 49.60 & 49.40 & 49.60 & 49.80 & & & & & & & \\
\hline \multirow[t]{2}{*}{ Lactose $(\mathrm{kg} / \mathrm{d})$} & $\mathrm{P}$ & 2.13 & 2.09 & 2.10 & 2.15 & 0.05 & 2.16 & 0.77 & 0.46 & 0.84 & 0.46 & 0.48 \\
\hline & M & 2.17 & 2.20 & 2.21 & 2.22 & & & & & & & \\
\hline \multirow[t]{2}{*}{$\mathrm{SNF}(\mathrm{g} / \mathrm{kg})$} & $\mathrm{P}$ & 89.20 & 89.00 & 89.00 & 89.50 & 0.88 & 88.38 & 0.93 & 0.69 & 0.81 & 0.68 & 0.64 \\
\hline & M & 87.50 & 87.40 & 87.90 & 87.50 & & & & & & & \\
\hline \multirow[t]{2}{*}{$\mathrm{SNF}(\mathrm{kg} / \mathrm{d})$} & $\mathrm{P}$ & 3.71 & 3.64 & 3.67 & 3.75 & 0.11 & 3.78 & 0.87 & 0.24 & 0.80 & 0.55 & 0.57 \\
\hline & M & 3.84 & 3.89 & 3.90 & 3.89 & & & & & & & \\
\hline \multirow[t]{2}{*}{ MUN (mg/dL) } & $\mathrm{P}$ & 11.69 & 11.68 & 11.41 & 12.24 & 73.00 & 12.02 & 0.04 & 0.29 & 0.21 & 0.01 & 0.58 \\
\hline & $\mathrm{M}$ & 11.01 & 12.42 & 12.40 & 13.36 & & & & & & & \\
\hline \multirow[t]{2}{*}{ SCC (cells/mL) } & $\mathrm{M}$ & 15,750 & 18,875 & 20,875 & 13,625 & 123,674 & 120,674 & 0.21 & 0.22 & 0.24 & 0.78 & 0.69 \\
\hline & $\mathrm{P}$ & 243,000 & 157,750 & 336,125 & 159,625 & & & & & & & \\
\hline \multicolumn{13}{|c|}{${ }^{1} \mathrm{TS}=$ tomato seed as $100 \%$ of the lipid supplement in TMR; HTS $=50 \%$ tomato seed $: 50 \%$ whole cottonseed as lipid supplement ratio in TMR; LTS $=25 \%$ tomato seed $: 75 \%$ who } \\
\hline
\end{tabular}


Table 7. Diet composition intake by lactating primiparous $(\mathrm{P})$ and multiparous $(\mathrm{M})$ dairy cows fed diets with varying amounts of tomato seed and whole cottonseed

\begin{tabular}{|c|c|c|c|c|c|c|c|c|c|c|c|c|}
\hline \multirow[b]{2}{*}{ Item } & \multirow[b]{2}{*}{ Parity } & \multicolumn{4}{|c|}{ Treatment $^{1}$} & \multirow[b]{2}{*}{ SEM } & \multirow[b]{2}{*}{$\mu^{2}$} & \multicolumn{5}{|c|}{$P$-value ${ }^{3}$} \\
\hline & & TS & HTS & LTS & CS & & & $\mathrm{TE}$ & $\mathrm{PE}$ & $\mathrm{PE} \times \mathrm{TE}$ & $\mathrm{L}$ & $\mathrm{Q}$ \\
\hline \multirow[t]{2}{*}{$\mathrm{DM}(\mathrm{kg})$} & $\mathrm{P}$ & 21.15 & 20.82 & 20.90 & 21.80 & 1.81 & 22.84 & 0.73 & 0.08 & 0.35 & 0.40 & 0.58 \\
\hline & $\mathrm{M}$ & 24.26 & 24.76 & 24.59 & 24.40 & & & & & & & \\
\hline \multirow[t]{2}{*}{$\mathrm{CP}(\mathrm{kg})$} & $\mathrm{P}$ & 3.50 & 3.50 & 3.50 & 3.60 & 0.30 & 3.80 & 0.96 & 0.06 & 0.88 & 0.69 & 0.81 \\
\hline & M & 4.01 & 4.15 & 4.11 & 4.04 & & & & & & & \\
\hline \multirow{2}{*}{ Ash-free NDF (kg) } & $\mathrm{P}$ & 8.44 & 9.17 & 8.42 & 8.29 & 0.88 & 9.27 & 0.08 & 0.07 & 0.92 & 0.59 & 0.03 \\
\hline & M & 9.66 & 10.84 & 9.87 & 9.45 & & & & & & & \\
\hline \multirow{2}{*}{ Ash-free ADF (kg) } & $\mathrm{P}$ & 4.58 & 4.88 & 4.73 & 4.85 & 0.44 & 5.14 & 0.11 & 0.06 & 0.83 & 0.12 & 0.11 \\
\hline & $\mathrm{M}$ & 5.24 & 5.77 & 5.56 & 5.51 & & & & & & & \\
\hline \multirow[t]{2}{*}{ Cellulose (kg) } & $\mathrm{P}$ & 3.60 & 3.84 & 3.75 & 3.83 & 0.35 & 4.10 & 0.10 & 0.04 & 0.83 & 0.07 & 0.11 \\
\hline & M & 4.11 & 4.54 & 4.41 & 4.36 & & & & & & & \\
\hline \multirow[t]{2}{*}{ DMI (\% BW) } & $\mathrm{P}$ & 3.47 & 3.40 & 3.42 & 3.57 & 0.09 & 3.40 & 0.73 & 0.08 & 0.35 & 0.38 & 0.41 \\
\hline & M & 3.29 & 3.38 & 3.33 & 3.30 & & & & & & & \\
\hline \multirow{2}{*}{$\mathrm{FA}(\mathrm{kg})$} & $\mathrm{P}$ & 0.67 & 0.71 & 0.71 & 0.72 & 0.06 & 0.76 & 0.67 & 0.09 & 0.96 & 0.38 & 0.43 \\
\hline & $\mathrm{M}$ & 0.76 & 0.85 & 0.83 & 0.80 & & & & & & & \\
\hline \multirow[t]{2}{*}{$\mathrm{C} 18: 2(\mathrm{~g})$} & $\mathrm{P}$ & 226.32 & 250.18 & 238.75 & 247.31 & 23.29 & 259.18 & 0.49 & 0.09 & 0.96 & 0.35 & 0.30 \\
\hline & $\mathrm{M}$ & 258.34 & 295.13 & 282.18 & 275.19 & & & & & & & \\
\hline \multirow[t]{2}{*}{$\mathrm{C} 18: 3(\mathrm{~g})$} & $\mathrm{P}$ & 36.94 & 38.62 & 36.18 & 35.12 & 3.63 & 39.52 & 0.48 & 0.02 & 0.95 & 0.39 & 0.20 \\
\hline & $\mathrm{M}$ & 42.66 & 45.07 & 43.07 & 38.52 & & & & & & & \\
\hline \multirow{2}{*}{ BW (kg) } & $\mathrm{P}$ & 608.93 & 613.78 & 613.37 & 610.70 & 66.75 & 674.08 & 0.74 & 0.002 & 0.57 & 0.38 & 0.10 \\
\hline & M & 735.69 & 731.81 & 738.92 & 739.45 & & & & & & & \\
\hline
\end{tabular}

${ }^{1} \mathrm{TS}=$ tomato seed as $100 \%$ of the lipid supplement in TMR; HTS $=50 \%$ tomato seed:50\% whole cottonseed as lipid supplement ratio in TMR; LTS $=25 \%$ tomato seed:75\% whole cottonseed as lipid supplement ratio in TMR; CS = whole cottonseed fed as $100 \%$ of the lipid supplement in TMR.

${ }^{2} \mu=$ overall mean.

${ }^{3}$ Probability of a significant effect of treatment $(\mathrm{TE})$, parity $(\mathrm{PE})$, treatment $\times$ parity interaction, or a linear $(\mathrm{L})$ or quadratic $(\mathrm{Q})$ effect of treatment. 
Table 8. Whole-tract apparent digestibility (\% of intake) of diets differing in proportion of tomato seed to whole cottonseed

\begin{tabular}{|c|c|c|c|c|c|c|c|c|c|c|c|c|}
\hline \multirow[b]{2}{*}{ Item } & \multirow[b]{2}{*}{ Parity $^{1}$} & \multicolumn{4}{|c|}{ Treatment $^{2}$} & \multirow[b]{2}{*}{ SEM } & \multirow[b]{2}{*}{$\mu^{3}$} & \multicolumn{5}{|c|}{$P$-value ${ }^{4}$} \\
\hline & & TS & HTS & LTS & CS & & & $\mathrm{TE}$ & $\mathrm{PE}$ & $\mathrm{PE} \times \mathrm{TE}$ & $\mathrm{L}$ & $\mathrm{Q}$ \\
\hline \multirow{2}{*}{$\overline{\mathrm{DM}}$} & $\mathrm{P}$ & 64.32 & 65.82 & 65.68 & 64.50 & 1.52 & 65.97 & 0.72 & 0.26 & 0.54 & 0.44 & 0.94 \\
\hline & $\mathrm{M}$ & 66.47 & 64.73 & 68.18 & 68.08 & & & & & & & \\
\hline \multirow[t]{2}{*}{ Protein } & $\mathrm{P}$ & 58.35 & 61.83 & 62.46 & 61.50 & 2.49 & 62.21 & 0.17 & 0.35 & 0.47 & 0.04 & 0.84 \\
\hline & M & 61.62 & 60.63 & 64.83 & 66.47 & & & & & & & \\
\hline \multirow[t]{2}{*}{ Ash-free NDF } & $\mathrm{P}$ & 54.69 & 59.54 & 55.32 & 51.10 & 2.62 & 56.09 & 0.06 & 0.50 & 0.42 & 0.16 & 0.02 \\
\hline & M & 57.43 & 57.67 & 57.63 & 55.07 & & & & & & & \\
\hline \multirow[t]{2}{*}{ Ash-free ADF } & $\mathrm{P}$ & 43.36 & 46.31 & 45.58 & 42.03 & 1.87 & 45.33 & 0.21 & 0.12 & 0.45 & 0.50 & 0.09 \\
\hline & M & 47.06 & 45.56 & 47.71 & 45.04 & & & & & & & \\
\hline \multirow{2}{*}{ Cellulose } & $\mathrm{P}$ & 55.24 & 58.36 & 57.21 & 52.94 & 2.12 & 57.07 & 0.07 & 0.22 & 0.48 & 0.50 & 0.02 \\
\hline & M & 58.00 & 58.10 & 59.80 & 56.88 & & & & & & & \\
\hline \multirow[t]{2}{*}{ Intake energy } & $\mathrm{P}$ & 62.28 & 63.34 & 63.98 & 62.51 & 1.88 & 63.84 & 0.52 & 0.23 & 0.61 & 0.29 & 0.90 \\
\hline & $\mathrm{M}$ & 62.24 & 62.91 & 66.78 & 66.69 & & & & & & & \\
\hline \multirow[t]{2}{*}{ FA } & $\mathrm{P}$ & 43.38 & 58.21 & 65.73 & 69.06 & 10.34 & 60.37 & 0.0001 & 0.52 & 0.98 & $<0.0001$ & 0.29 \\
\hline & $\mathrm{M}$ & 46.37 & 62.26 & 67.72 & 70.21 & & & & & & & \\
\hline \multirow[t]{2}{*}{$\mathrm{C} 18: 2$} & $\mathrm{P}$ & 58.48 & 79.82 & 86.37 & 88.38 & 12.32 & 79.37 & $<0.0001$ & 0.63 & 0.82 & $<0.0001$ & 0.20 \\
\hline & M & 63.33 & 78.66 & 87.29 & 92.63 & & & & & & & \\
\hline \multirow[t]{2}{*}{ C18:3n-3 } & $\mathrm{P}$ & 87.36 & 92.19 & 93.28 & 94.02 & 2.89 & 91.95 & 0.0005 & 0.75 & 0.79 & $<0.0001$ & 0.55 \\
\hline & $\mathrm{M}$ & 88.15 & 91.16 & 94.06 & 95.36 & & & & & & & \\
\hline
\end{tabular}

${ }^{1} \mathrm{P}=$ primiparous; $\mathrm{M}=$ multiparous

c. $\quad{ }^{2} \mathrm{TS}=$ tomato seed as $100 \%$ of the lipid supplement in TMR; HTS $=50 \%$ tomato seed:50\% whole cottonseed as lipid supplement ratio in TMR; LTS $=25 \%$ tomato seed: $75 \%$ whole

cottonseed as lipid supplement ratio in TMR; CS = whole cottonseed fed as $100 \%$ of the lipid supplement in TMR.

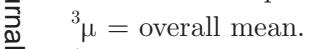

Probability of a significant effect of treatment (TE), parity (PE), treatment $\times$ parity interaction, or a linear (L) or quadratic (Q) effect of treatment. 
was attributed to reduced fermentation in the rumen due to increased ruminal $\mathrm{pH}$ values (Yuangklang et al., 2010a). In another study, when dried tomato pomace was fed to steers, DMI did not change at the same feeding levels of 3.2, 8.0, and 11.2\% DM (Yuangklang et al., 2010b). However, the studies of Yuangklang et al. $(2010 \mathrm{a}, \mathrm{b})$ were confounded because dietary urea increased as tomato pomace increased, which could affect interpretations related to rumen $\mathrm{pH}$. In lactating dairy cattle, Weiss et al. (1997) found no differences in DMI when tomato pomace ensiled with corn plants was fed at $7.2 \%$ of the DM.

Whole-tract apparent digestibility (Table 8 ) of DM did not differ, but ash-free NDF digestibility $(P<$ 0.02 ; quadratic) and ash-free ADF digestibility $(P<$ 0.09 ; quadratic) differed in a pattern that tended to reflect the NDF and ADF concentration of the diet. The reason for this response is not apparent to us. Apparent digestibility of total FA and $\mathrm{CP}$ decreased as the proportion of WTS to WCS increased. Hinman et al. (1978) showed slightly higher digestion coefficients for $\mathrm{EE}$ when dried tomato pomace was fed at varying levels to sheep. The decrease in CP digestibility in the current study with WTS agrees with studies conducted with sheep and cattle fed tomato pomace. Crude protein digestibility was reported to decrease in studies where tomato pomace was fed to sheep (Hinman et al., 1978; Fondevila et al., 1994; Abbeddou et al., 2011a), which was attributed to lower digestibility in the small intestine of the undegraded pomace protein (Fondevila et al., 1994). Using an in sacco approach with sheep, Fondevila et al. (1994) exposed tomato pomace and soybean meal to rumen fermentation. The residues in the nylon bags were subjected to $\mathrm{HCl}$-pepsin treatment. Tomato pomace had lower $\mathrm{HCl}$-pepsin solubility compared with soybean meal. This difference in conjunction with the higher ADF-N for tomato pomace than soybean meal was used to propose that the undegraded protein of tomato pomace had low postruminal digestion. Weiss et al. (1997) ensiled tomato pomace with corn forage. The tomato pomace had $19.7 \%$ of the $\mathrm{N}$ as acid-detergent-insoluble nitrogen, but apparent digestibility of dietary protein was not affected by the inclusion of tomato pomace. We did not explore the degradability of ADF-bound nitrogen. Beef steers showed a decrease in CP digestibility when tomato pomace replaced soybean meal (Yuangklang et al., 2010b). However, because dietary urea concentration increased with increasing proportion of tomato pomace, CP digestibility estimates are confounded because urea $\mathrm{N}$ is part of $\mathrm{CP}$, but any urea $\mathrm{N}$ absorbed from the rumen could be excreted via the urine and not feces (Yuangklang et al., 2010b). Likewise, Abbeddou et al. (2011b) also reported lower CP digestibility with to- 
mato pomace in the diet. However, these authors stated in the text that urea was added to the diet to balance dietary $\mathrm{N}$, but this urea was not reported in the table of ingredient composition of the diets. The authors added up to $6 \mathrm{~g}$ of urea $/ \mathrm{kg}$ of DM $(2.8 \mathrm{~g}$ of $\mathrm{N} / \mathrm{kg}$ of DM) and the diets contained approximately $24 \mathrm{~g}$ of $\mathrm{N} / \mathrm{kg}$ of $\mathrm{DM}$, so urea $\mathrm{N}$ contributed about $12 \%$ of the total dietary $\mathrm{N}$ intake. Dietary urea would likely be excreted in the urine and not feces, so their data are confounded with respect to protein digestibility.

Apparent digestibility of total FA decreased with increasing WTS in the diet. Other authors reported high digestibility of $\mathrm{EE}$ for diets containing tomato pomace, for example as high as $80 \%$ (Yuangklang et al., 2010b; Abbeddou et al., 2011b). One obvious reason for this large discrepancy among studies is WTS were fed to dairy cattle in the current study, but in the other studies tomato pomace was fed to sheep or beef cattle. However, it may be more relevant to address analytical methods. For example, Abbeddou et al. (2011b) used $\mathrm{EE}$ with petroleum ether to determine total lipids. If it is true with respect to what we observed with EE, then using EE would underestimate the amount of tomato lipid fed as well as the amount of tomato lipid in the feces. In addition, any FA in the salt form in the feces would not be extracted with solvent unless acidified (Andrews and Lewis, 1970), so the error for fecal lipid would be greater than feed lipid. These underestimations would likely result in a prediction that lipid digestion of EE was high. In contrast, the method for FA determination does not have these analytical limitations.

Apparent digestibility of C18:2 and C18:3 followed a pattern similar to total FA (Table 8). Typically, digestibility of C18:2 and C18:3 might not be measured because there is rumen biohydrogenation of dietary unsaturated FA. However, WTS were visible in screened samples of feces. Even though an original objective was to quantify any WTS in the feces, the amount of WTS could not be easily quantified. If WTS were passing through the digestive tract undigested, it would be expected that digestibility of $\mathrm{C} 18: 2$ and $\mathrm{C} 18: 3$ would decrease and support the observations for total FA digestibility. Indeed, increased $(P<0.001)$ fecal concentration of both C18:2 and C18:3 occurred with increasing proportion of WTS in the diet. This observation, along with the lower $\mathrm{CP}$ whole-tract apparent digestibility, supports the passage of a portion of the WTS through the digestive tract undigested (Table 8 ) because intakes of $\mathrm{C} 18: 2$ and C18:3 were not different for diet (Table $6)$. Because the concentration of C18:3 increased and C18:2 tended to increase with increasing WTS, some of the WTS lipid that likely passed as whole seed from the rumen was digested in the small intestine and the C18:2 and C18:3 used for milk fat synthesis. However, the yields of C18:2 and C18:3 in milk fat were not different, suggesting that the majority of WTS that passed from the rumen were not digested postruminally as a bypass source of unsaturated FA. In agreement, Abbeddou et al. (2011a) observed no change in the PUFA content of yogurt and cheese when sheep were fed tomato pomace, supporting a lack of rumen bypass of unsaturated FA.

Milk energy output and milk fat yield (Table 6) were reduced with WTS. Yield of C18:0 (Table 11) was lower with WTS. With reduced total FA digestibility (Table 8), preformed FA for milk fat synthesis would be less, which supports the lower yield of C18:0 and lower milk energy output observed. The lower yield of cis-9 and cis-10 C18:1 could also reflect the lower digestibility of C18:0 so there would be less substrate for mammary desaturation.

In the current study, MUN (Table 6) and PUN (Table 9) decreased with increased proportion of WTS in the diet. Because neither intake of CP (Table 7) nor yield of milk protein (Table 6) differed for diet and the fact that WTS contained more CP than WCS (Table 2), the lower MUN and PUN with tomato seed further supports that the digestibility of WTS was reduced in the rumen and postuminally. In contrast, BUN in steers increased as the tomato pomace concentration increased in the diets from 0 to a high of $11.2 \%$ of DM (Yuangklang et al., 2010a,b). These researchers suggested that the increase in BUN with increased proportion of tomato pomace in the diet occurred because of increased ruminal ammonia concentrations that would subsequently be converted to urea in the liver. However, the results of Yuangklang et al. (2010a,b) should be viewed with caution because urea was added to diets to balance dietary concentration of $\mathrm{N}$. As the proportion of tomato pomace in the diet increased, so did the amount of dietary urea, and the increasing dietary urea could account for observed changes in BUN and not the tomato pomace.

Milk concentrations of trans-10 C18:1, trans-11 $\mathrm{C} 18: 1$, and trans-10,cis-12 C18:2, intermediates of rumen biohydrogenation of cis-9,cis-12 C18:2, were not affected by dietary treatment (Table 10). However, concentration of cis-9,trans-11 C18:2, also a biohydrogenation intermediate, increased with increasing dietary WTS. Yields of several trans C18:1 FA and cis-12 C18:1 increased with increasing proportion of WCS in the diet, which could possibly indicate a shift in the biohydrogenation pathways in the rumen. An alternate pathway for rumen biohydrogenation involves trans-10,cis-12 C18:2 converted to trans-10 C18:1, but the concentration of neither of these FA was affected by diet. However, yield of trans-10 C18:1 tended $(P<0.06)$ to increase as the proportion of WTS to 
Table 10. Concentration ( $\mathrm{g}$ of FA/100 g of FA) of milk FA of cows fed varying proportions of tomato seed and whole cottonseed

\begin{tabular}{|c|c|c|c|c|c|c|c|c|c|c|c|c|}
\hline \multirow[b]{2}{*}{ FA } & \multirow[b]{2}{*}{ Parity $^{1}$} & \multicolumn{4}{|c|}{ Treatment ${ }^{2}$} & \multirow[b]{2}{*}{ SEM } & \multirow[b]{2}{*}{$\mu^{3}$} & \multicolumn{5}{|c|}{$P$-value ${ }^{4}$} \\
\hline & & $\mathrm{TS}$ & HTS & LTS & WCS & & & $\mathrm{TE}$ & $\mathrm{PE}$ & $\mathrm{PE} \times \mathrm{TE}$ & $\mathrm{L}$ & $\mathrm{Q}$ \\
\hline \multirow[t]{2}{*}{$\mathrm{C} 4: 0$} & $\mathrm{P}$ & 2.98 & 3.39 & 3.09 & 3.00 & 0.13 & 3.10 & 0.06 & 0.89 & 0.22 & 0.87 & 0.01 \\
\hline & M & 3.03 & 3.11 & 3.15 & 3.04 & & & & & & & \\
\hline \multirow[t]{2}{*}{ C6:0 } & $\mathrm{P}$ & 2.33 & 2.38 & 2.30 & 2.30 & 0.07 & 2.27 & 0.69 & 0.47 & 0.28 & 0.62 & 0.28 \\
\hline & M & 2.17 & 2.20 & 2.28 & 2.22 & & & & & & & \\
\hline \multirow{2}{*}{ C8:0 } & $\mathrm{P}$ & 1.50 & 1.49 & 1.44 & 1.45 & 0.06 & 1.42 & 0.98 & 0.37 & 0.31 & 0.69 & 0.98 \\
\hline & M & 1.35 & 1.35 & 1.39 & 1.38 & & & & & & & \\
\hline \multirow[t]{2}{*}{ C9:0 } & $\mathrm{P}$ & 0.07 & 0.06 & 0.05 & 0.06 & 0.007 & 0.06 & 0.16 & 0.68 & 0.22 & 0.21 & 0.16 \\
\hline & M & 0.07 & 0.06 & 0.06 & 0.07 & & & & & & & \\
\hline \multirow[t]{2}{*}{ C10:0 } & $\mathrm{P}$ & 4.01 & 3.89 & 3.69 & 3.73 & 0.16 & 3.71 & 0.34 & 0.51 & 0.41 & 0.12 & 0.16 \\
\hline & M & 3.63 & 3.54 & 3.57 & 3.63 & & & & & & & \\
\hline \multirow{2}{*}{$\mathrm{C} 11: 0$} & $\mathrm{P}$ & 0.12 & 0.10 & 0.09 & 0.10 & 0.02 & 0.11 & 0.04 & 0.62 & 0.98 & 0.04 & 0.04 \\
\hline & M & 0.14 & 0.11 & 0.11 & 0.12 & & & & & & & \\
\hline \multirow[t]{2}{*}{$\mathrm{C} 12: 0$} & $\mathrm{P}$ & 4.58 & 4.35 & 4.11 & 4.13 & 0.17 & 4.23 & 0.05 & 0.79 & 0.51 & 0.01 & 0.34 \\
\hline & $\mathrm{M}$ & 4.31 & 4.13 & 4.07 & 4.17 & & & & & & & \\
\hline \multirow[t]{2}{*}{$\mathrm{C} 13: 0$} & $\mathrm{P}$ & 0.28 & 0.23 & 0.22 & 0.23 & 0.03 & 0.25 & 0.01 & 0.48 & 0.78 & 0.005 & 0.03 \\
\hline & M & 0.30 & 0.26 & 0.25 & 0.27 & & & & & & & \\
\hline \multirow[t]{2}{*}{ C14:0 } & $\mathrm{P}$ & 12.80 & 12.49 & 11.98 & 11.85 & 0.37 & 12.44 & 0.04 & 0.60 & 0.60 & 0.006 & 0.95 \\
\hline & M & 12.92 & 12.55 & 12.51 & 12.42 & & & & & & & \\
\hline \multirow[t]{2}{*}{ cis $\mathrm{C} 14: 1$} & $\mathrm{P}$ & 0.77 & 0.69 & 0.66 & 0.63 & 0.14 & 0.79 & 0.0002 & 0.08 & 0.42 & $<0.0001$ & 0.05 \\
\hline & M & 1.04 & 0.89 & 0.84 & 0.83 & & & & & & & \\
\hline \multirow[t]{2}{*}{ C15:0 } & $\mathrm{P}$ & 1.39 & 1.25 & 1.16 & 1.21 & 0.10 & 1.31 & 0.004 & 0.48 & 0.74 & 0.001 & 0.31 \\
\hline & M & 1.46 & 1.34 & 1.31 & 1.35 & & & & & & & \\
\hline \multirow[t]{2}{*}{ C16:0 } & $\mathrm{P}$ & 30.68 & 30.52 & 29.31 & 29.55 & 0.55 & 29.80 & 0.32 & 0.78 & 0.21 & 0.07 & 0.96 \\
\hline & $\mathrm{M}$ & 29.85 & 29.23 & 29.89 & 29.39 & & & & & & & \\
\hline trans $\mathrm{C} 16: 1$ & $\mathrm{P}$ & 0.32 & 0.30 & 0.31 & 0.30 & 0.01 & 0.31 & 0.29 & 0.85 & 0.48 & 0.14 & 0.56 \\
\hline & M & 0.32 & 0.32 & 0.32 & 0.32 & & & & & & & \\
\hline cis $\mathrm{C} 16: 1$ & $\mathrm{P}$ & 1.36 & 1.09 & 1.21 & 1.27 & 0.12 & 1.17 & 0.006 & 0.61 & 0.25 & 0.01 & 0.01 \\
\hline & M & 1.26 & 1.08 & 1.03 & 1.05 & & & & & & & \\
\hline C17:0 & $\mathrm{P}$ & 0.78 & 0.72 & 0.69 & 0.70 & 0.03 & 0.74 & 0.003 & 0.58 & 0.33 & 0.0005 & 0.20 \\
\hline & M & 0.78 & 0.75 & 0.74 & 0.73 & & & & & & & \\
\hline trans $\mathrm{C} 17: 1$ & $\mathrm{P}$ & 0.07 & 0.07 & 0.05 & 0.04 & 0.01 & 0.06 & $<0.0001$ & 0.85 & 0.59 & $<0.0001$ & 0.16 \\
\hline & $\mathrm{M}$ & 0.08 & 0.06 & 0.05 & 0.04 & & & & & & & \\
\hline C18:0 & $\mathrm{P}$ & 9.24 & 10.43 & 10.46 & 10.74 & 0.78 & 9.99 & 0.001 & 0.45 & 0.73 & 0.0002 & 0.07 \\
\hline & $\mathrm{M}$ & 8.41 & 10.00 & 10.41 & 10.23 & & & & & & & \\
\hline trans-5 C18:1 & $\mathrm{P}$ & 0.02 & 0.02 & 0.02 & 0.02 & 0.00 & 0.02 & 0.66 & 0.36 & 0.81 & 0.47 & 0.55 \\
\hline & M & 0.02 & 0.02 & 0.02 & 0.02 & & & & & & & \\
\hline trans-7 C18:1 & $\mathrm{P}$ & 0.02 & 0.02 & 0.02 & 0.02 & 0.00 & 0.02 & 0.52 & 0.69 & 0.02 & 0.29 & 0.44 \\
\hline & $\mathrm{M}$ & 0.02 & 0.02 & 0.02 & 0.02 & & & & & & & \\
\hline trans- 6 and trans- 8 C18:1 & $\mathrm{P}$ & 0.2 & 0.20 & 0.21 & 0.22 & 0.01 & 0.21 & 0.18 & 1.00 & 0.61 & 0.06 & 0.44 \\
\hline & M & 0.2 & 0.21 & 0.21 & 0.23 & & & & & & & \\
\hline trans-9 C18:1 & $\mathrm{P}$ & 0.24 & 0.25 & 0.24 & 0.25 & 0.02 & 0.26 & 0.25 & 0.42 & 0.53 & 0.47 & 0.28 \\
\hline & $\mathrm{M}$ & 0.25 & 0.3 & 0.26 & 0.28 & & & & & & & \\
\hline trans-10 C18:1 & $\mathrm{P}$ & 0.30 & 0.27 & 0.36 & 0.38 & 0.08 & 0.38 & 0.16 & 0.39 & 0.58 & 0.28 & 0.05 \\
\hline & $\mathrm{M}$ & 0.47 & 0.36 & 0.39 & 0.54 & & & & & & & \\
\hline trans-11 C18:1 & $\mathrm{P}$ & 0.86 & 0.78 & 0.80 & 0.81 & 0.05 & 0.77 & 0.63 & 0.26 & 0.94 & 0.54 & 0.27 \\
\hline & $\mathrm{M}$ & 0.75 & 0.72 & 0.72 & 0.75 & & & & & & & \\
\hline trans-12 C18:1 & $\mathrm{P}$ & 0.28 & 0.29 & 0.34 & 0.38 & 0.04 & 0.35 & 0.005 & 0.38 & 0.54 & 0.001 & 0.09 \\
\hline & M & 0.34 & 0.37 & 0.36 & 0.41 & & & & & & & \\
\hline
\end{tabular}


Table 10 (Continued). Concentration ( $\mathrm{g}$ of FA/100 g of FA) of milk FA of cows fed varying proportions of tomato seed and whole cottonseed

\begin{tabular}{|c|c|c|c|c|c|c|c|c|c|c|c|c|}
\hline \multirow[b]{2}{*}{ FA } & \multirow[b]{2}{*}{ Parity $^{1}$} & \multicolumn{4}{|c|}{ Treatment $^{2}$} & \multirow[b]{2}{*}{ SEM } & \multirow[b]{2}{*}{$\mu^{3}$} & \multicolumn{5}{|c|}{$P$-value ${ }^{4}$} \\
\hline & & TS & HTS & LTS & WCS & & & $\mathrm{TE}$ & $\mathrm{PE}$ & $\mathrm{PE} \times \mathrm{TE}$ & $\mathrm{L}$ & $\mathrm{Q}$ \\
\hline \multirow[t]{2}{*}{ trans-13 and trans-14 C18:1 } & $\mathrm{P}$ & 0.61 & 0.61 & 0.73 & 0.82 & 0.11 & 0.76 & 0.005 & 0.22 & 0.48 & 0.001 & 0.07 \\
\hline & M & 0.76 & 0.82 & 0.80 & 0.94 & & & & & & & \\
\hline \multirow[t]{2}{*}{ cis-9 and cis-10 C18:1 } & $\mathrm{P}$ & 14.13 & 14.19 & 16.63 & 16.29 & 0.98 & 15.65 & 0.47 & 0.62 & 0.28 & 0.16 & 0.89 \\
\hline & M & 15.69 & 16.58 & 15.84 & 15.81 & & & & & & & \\
\hline \multirow[t]{2}{*}{ cis-11 C18:1 } & $\mathrm{P}$ & 0.56 & 0.50 & 0.51 & 0.53 & 0.02 & 0.51 & 0.11 & 0.80 & 0.40 & 0.05 & 0.18 \\
\hline & M & 0.53 & 0.53 & 0.47 & 0.50 & & & & & & & \\
\hline \multirow[t]{2}{*}{ cis-12 C18:1 } & $\mathrm{P}$ & 0.31 & 0.30 & 0.35 & 0.39 & 0.06 & 0.37 & 0.12 & 0.43 & 0.67 & 0.12 & 0.06 \\
\hline & $\mathrm{M}$ & 0.41 & 0.37 & 0.36 & 0.48 & & & & & & & \\
\hline \multirow[t]{2}{*}{ cis-13 C18:1 } & $\mathrm{P}$ & 0.05 & 0.05 & 0.06 & 0.05 & 0.005 & 0.06 & 0.41 & 0.45 & 0.62 & 0.30 & 0.32 \\
\hline & M & 0.06 & 0.05 & 0.06 & 0.06 & & & & & & & \\
\hline \multirow[t]{2}{*}{ trans-16 C18:1 } & $\mathrm{P}$ & 0.26 & 0.27 & 0.32 & 0.35 & 0.04 & 0.32 & 0.005 & 0.23 & 0.35 & 0.0006 & 0.57 \\
\hline & M & 0.30 & 0.35 & 0.35 & 0.36 & & & & & & & \\
\hline \multirow[t]{2}{*}{$\mathrm{C} 18: 2$} & $\mathrm{P}$ & 3.47 & 3.39 & 3.35 & 3.42 & 0.09 & 3.36 & 0.08 & 0.82 & 0.86 & 0.08 & 0.09 \\
\hline & M & 3.42 & 3.29 & 3.20 & 3.31 & & & & & & & \\
\hline \multirow[t]{2}{*}{$\mathrm{C} 20$} & $\mathrm{P}$ & 0.13 & 0.15 & 0.14 & 0.14 & 0.01 & 0.13 & 0.03 & 0.02 & 0.54 & 0.04 & 0.02 \\
\hline & M & 0.11 & 0.13 & 0.14 & 0.13 & & & & & & & \\
\hline \multirow[t]{2}{*}{ C18:3n-6 } & $\mathrm{P}$ & 0.03 & 0.03 & 0.03 & 0.04 & 0.005 & 0.04 & 0.26 & 0.31 & 0.53 & 0.06 & 0.67 \\
\hline & M & 0.03 & 0.04 & 0.04 & 0.04 & & & & & & & \\
\hline \multirow{2}{*}{ C18:3n-3 } & $\mathrm{P}$ & 0.78 & 0.76 & 0.74 & 0.75 & 0.03 & 0.76 & 0.03 & 0.99 & 0.62 & 0.007 & 0.67 \\
\hline & M & 0.81 & 0.77 & 0.72 & 0.73 & & & & & & & \\
\hline \multirow[t]{2}{*}{ cis-9,trans11 C18:2 } & $\mathrm{P}$ & 0.60 & 0.51 & 0.36 & 0.35 & 0.10 & 0.41 & 0.10 & 0.22 & 0.46 & 0.02 & 0.78 \\
\hline & M & 0.41 & 0.35 & 0.32 & 0.35 & & & & & & & \\
\hline \multirow{2}{*}{ trans-10,cis-12 C18:2 } & $\mathrm{P}$ & 0.003 & 0.008 & 0.01 & 0.003 & 0.003 & 0.006 & 0.36 & 0.84 & 0.26 & 0.44 & 0.12 \\
\hline & M & 0.005 & 0.008 & 0.005 & 0.008 & & & & & & & \\
\hline \multirow{2}{*}{ All trans C18:2 } & $\mathrm{P}$ & 0.010 & 0.013 & 0.008 & 0.013 & 0.003 & 0.012 & 0.44 & 0.48 & 0.73 & 0.49 & 0.68 \\
\hline & M & 0.015 & 0.018 & 0.010 & 0.010 & & & & & & & \\
\hline \multirow[t]{2}{*}{ C20:3 } & $\mathrm{P}$ & 0.16 & 0.14 & 0.14 & 0.15 & 0.01 & 0.16 & 0.18 & 0.22 & 0.89 & 0.40 & 0.04 \\
\hline & M & 0.17 & 0.16 & 0.16 & 0.17 & & & & & & & \\
\hline \multirow[t]{2}{*}{ C20:4 } & $\mathrm{P}$ & 0.21 & 0.19 & 0.19 & 0.19 & 0.009 & 0.19 & 0.23 & 0.37 & 0.43 & 0.24 & 0.09 \\
\hline & M & 0.19 & 0.18 & 0.18 & 0.19 & & & & & & & \\
\hline C20:5 & $\mathrm{P}$ & 0.05 & 0.04 & 0.05 & 0.05 & 0.007 & 0.05 & 0.51 & 0.20 & 0.36 & 0.32 & 0.43 \\
\hline & M & 0.06 & 0.06 & 0.06 & 0.06 & & & & & & & \\
\hline C22:4n-6 & $\mathrm{P}$ & 0.05 & 0.06 & 0.17 & 0.05 & 0.04 & 0.06 & 0.36 & 0.15 & 0.43 & 0.68 & 0.40 \\
\hline & $\mathrm{M}$ & 0.04 & 0.04 & 0.04 & 0.03 & & & & & & & \\
\hline $\mathrm{C} 22: 5 n-6$ & $\mathrm{P}$ & 0.02 & 0.01 & 0.02 & 0.01 & 0.005 & 0.02 & 0.40 & 0.39 & 0.29 & 0.09 & 0.85 \\
\hline & $\mathrm{M}$ & 0.02 & 0.02 & 0.02 & 0.02 & & & & & & & \\
\hline C22:5n-3 & $\mathrm{P}$ & 0.11 & 0.10 & 0.10 & 0.10 & 0.004 & 0.10 & 0.65 & 0.84 & 0.68 & 0.34 & 0.42 \\
\hline & M & 0.10 & 0.10 & 0.10 & 0.10 & & & & & & & \\
\hline $\mathrm{C} 22: 6$ & $\mathrm{P}$ & 0.012 & 0.010 & 0.013 & 0.013 & 0.003 & 0.01 & 0.97 & 0.17 & 0.94 & 0.71 & 0.91 \\
\hline & M & 0.005 & 0.008 & 0.008 & 0.008 & & & & & & & \\
\hline Unknown & $\mathrm{P}$ & 3.27 & 3.42 & 3.30 & 2.99 & 0.21 & 3.29 & 0.09 & 0.55 & 0.09 & 0.01 & 0.86 \\
\hline & M & 3.73 & 3.20 & 3.20 & 3.24 & & & & & & & \\
\hline
\end{tabular}




\begin{tabular}{|c|c|c|c|c|c|c|c|c|c|c|c|c|}
\hline \multirow[b]{2}{*}{ FA } & \multirow[b]{2}{*}{ Parity $^{1}$} & \multicolumn{4}{|c|}{ Treatment $t^{2}$} & \multirow[b]{2}{*}{ SEM } & \multirow[b]{2}{*}{$\mu^{3}$} & \multicolumn{5}{|c|}{$P$-value ${ }^{4}$} \\
\hline & & TS & HTS & LTS & WCS & & & $\mathrm{TE}$ & $\mathrm{PE}$ & $\mathrm{PE} \times \mathrm{TE}$ & L & $\mathrm{Q}$ \\
\hline \multirow[t]{2}{*}{$\mathrm{C} 4: 0$} & $\mathrm{P}$ & 42.46 & 48.94 & 46.17 & 43.87 & 2.73 & 45.73 & 0.21 & 0.88 & 0.12 & 0.14 & 0.19 \\
\hline & $\mathrm{M}$ & 44.25 & 43.12 & 49.78 & 47.23 & & & & & & & \\
\hline \multirow[t]{2}{*}{ C6:0 } & $\mathrm{P}$ & 33.17 & 34.32 & 34.47 & 33.72 & 1.59 & 33.69 & 0.17 & 0.91 & 0.28 & 0.11 & 0.95 \\
\hline & M & 32.06 & 31.06 & 36.14 & 34.55 & & & & & & & \\
\hline \multirow[t]{2}{*}{ C8:0 } & $\mathrm{P}$ & 21.41 & 21.43 & 21.56 & 21.16 & 0.96 & 21.02 & 0.32 & 0.79 & 0.31 & 0.29 & 0.63 \\
\hline & $\mathrm{M}$ & 20.05 & 19.09 & 22.02 & 21.45 & & & & & & & \\
\hline \multirow[t]{2}{*}{ C9:0 } & $\mathrm{P}$ & 0.95 & 0.88 & 0.79 & 0.81 & 0.11 & 0.92 & 0.38 & 0.66 & 0.28 & 0.56 & 0.12 \\
\hline & $\mathrm{M}$ & 1.01 & 0.88 & 0.95 & 1.11 & & & & & & & \\
\hline \multirow[t]{2}{*}{ C10:0 } & $\mathrm{P}$ & 57.16 & 55.68 & 55.54 & 54.64 & 2.17 & 55.04 & 0.60 & 0.86 & 0.44 & 0.87 & 0.38 \\
\hline & M & 54.08 & 50.29 & 56.37 & 56.56 & & & & & & & \\
\hline \multirow[t]{2}{*}{ C11:0 } & $\mathrm{P}$ & 1.79 & 1.40 & 1.35 & 1.52 & 0.26 & 1.67 & 0.04 & 0.62 & 0.91 & 0.09 & 0.02 \\
\hline & $\mathrm{M}$ & 2.08 & 1.62 & 1.64 & 1.94 & & & & & & & \\
\hline \multirow[t]{2}{*}{ C12:0 } & $\mathrm{P}$ & 65.35 & 62.11 & 61.88 & 60.46 & 2.44 & 62.78 & 0.52 & 0.95 & 0.52 & 0.56 & 0.27 \\
\hline & M & 64.34 & 58.57 & 64.22 & 65.30 & & & & & & & \\
\hline \multirow[t]{2}{*}{ C13:0 } & $\mathrm{P}$ & 3.98 & 3.30 & 3.34 & 3.35 & 0.44 & 3.79 & 0.03 & 0.52 & 0.63 & 0.06 & 0.02 \\
\hline & M & 4.44 & 3.68 & 3.92 & 4.27 & & & & & & & \\
\hline \multirow[t]{2}{*}{ C14:0 } & $\mathrm{P}$ & 182.14 & 179.35 & 180.13 & 173.52 & 8.22 & 183.36 & 0.35 & 0.59 & 0.28 & 0.98 & 0.60 \\
\hline & M & 187.86 & 175.10 & 197.29 & 191.45 & & & & & & & \\
\hline \multirow[t]{2}{*}{ cis $\mathrm{C} 14: 1$} & $\mathrm{P}$ & 11.04 & 9.85 & 9.93 & 9.24 & 2.05 & 11.73 & 0.003 & 0.15 & 0.46 & 0.001 & 0.11 \\
\hline & M & 15.15 & 12.46 & 13.33 & 12.87 & & & & & & & \\
\hline \multirow[t]{2}{*}{ C15:0 } & $\mathrm{P}$ & 20.03 & 18.14 & 17.42 & 17.81 & 1.58 & 19.40 & 0.08 & 0.53 & 0.36 & 0.09 & 0.05 \\
\hline & $\mathrm{M}$ & 21.58 & 18.67 & 20.63 & 20.89 & & & & & & & \\
\hline C16:0 & $\mathrm{P}$ & 437.29 & 443.45 & 443.13 & 433.55 & 18.37 & 443.10 & 0.23 & 0.90 & 0.18 & 0.32 & 0.65 \\
\hline & $\mathrm{M}$ & 440.26 & 412.48 & 475.05 & 459.59 & & & & & & & \\
\hline trans $\mathrm{C} 16: 1$ & $\mathrm{P}$ & 4.60 & 4.35 & 4.66 & 4.40 & 0.23 & 4.59 & 0.15 & 0.54 & 0.52 & 0.48 & 0.43 \\
\hline & $\mathrm{M}$ & 4.57 & 4.31 & 4.96 & 4.84 & & & & & & & \\
\hline cis $\mathrm{C} 16: 1$ & $\mathrm{P}$ & 19.35 & 16.07 & 18.73 & 18.58 & 1.60 & 17.27 & 0.02 & 0.68 & 0.77 & 0.20 & 0.01 \\
\hline & M & 18.08 & 14.94 & 16.10 & 16.34 & & & & & & & \\
\hline C17:0 & $\mathrm{P}$ & 11.21 & 10.37 & 10.40 & 10.25 & 0.57 & 10.89 & 0.37 & 0.62 & 0.56 & 0.42 & 0.25 \\
\hline & M & 11.44 & 10.44 & 11.59 & 11.43 & & & & & & & \\
\hline trans $\mathrm{C} 17: 1$ & $\mathrm{P}$ & 1.04 & 0.98 & 0.79 & 0.59 & 0.21 & 0.83 & $<.0001$ & 0.55 & 0.45 & $<.0001$ & 0.21 \\
\hline & M & 1.13 & 0.83 & 0.74 & 0.56 & & & & & & & \\
\hline C18:0 & $\mathrm{P}$ & 131.42 & 150.53 & 156.90 & 157.59 & 14.70 & 148.60 & 0.004 & 0.96 & 0.62 & 0.0006 & 0.48 \\
\hline & M & 125.07 & 140.50 & 165.23 & 161.55 & & & & & & & \\
\hline trans-5 C18:1 & $\mathrm{P}$ & 0.25 & 0.25 & 0.34 & 0.25 & 0.05 & 0.30 & 0.29 & 0.36 & 0.86 & 0.20 & 0.61 \\
\hline & $\mathrm{M}$ & 0.27 & 0.30 & 0.36 & 0.35 & & & & & & & \\
\hline trans-7 C18:1 & $\mathrm{P}$ & 0.29 & 0.22 & 0.30 & 0.25 & 0.03 & 0.27 & 0.76 & 0.66 & 0.04 & 0.998 & 0.30 \\
\hline & $\mathrm{M}$ & 0.27 & 0.30 & 0.23 & 0.31 & & & & & & & \\
\hline trans- 6 and trans- 8 C18: 1 & $\mathrm{P}$ & 2.94 & 2.97 & 3.20 & 3.19 & 0.21 & 3.08 & 0.05 & 0.90 & 0.63 & 0.009 & 0.44 \\
\hline & M & 2.79 & 2.94 & 3.19 & 3.45 & & & & & & & \\
\hline trans-9 C18:1 & $\mathrm{P}$ & 3.47 & 3.64 & 3.56 & 3.67 & 0.29 & 3.78 & 0.35 & 0.14 & 0.70 & 0.09 & 0.64 \\
\hline & M & 3.55 & 4.01 & 4.17 & 4.18 & & & & & & & \\
\hline tran-10 C18:1 & $\mathrm{P}$ & 4.32 & 3.94 & 5.44 & 5.55 & 1.18 & 5.49 & 0.04 & 0.27 & 0.60 & 0.06 & 0.03 \\
\hline & M & 6.20 & 4.81 & 5.97 & 7.66 & & & & & & & \\
\hline trans-11 C18:1 & $\mathrm{P}$ & 12.25 & 11.26 & 11.95 & 11.81 & 0.75 & 11.34 & 0.44 & 0.40 & 0.81 & 0.68 & 0.23 \\
\hline & M & 10.73 & 9.89 & 11.28 & 11.55 & & & & & & & \\
\hline trans-12 C18:1 & $\mathrm{P}$ & 4.13 & 4.28 & 5.08 & 5.54 & 0.70 & 5.07 & 0.0002 & 0.19 & 0.99 & $<.0001$ & 0.05 \\
\hline & M & 4.73 & 5.00 & 5.65 & 6.17 & & & & & & & \\
\hline trans -13 and trans- 14 C18:1 & $\mathrm{P}$ & 8.87 & 9.07 & 10.97 & 12.05 & 1.74 & 11.20 & 0.0002 & 0.06 & 0.98 & $<.0001$ & 0.03 \\
\hline & M & 10.71 & 11.20 & 12.65 & 14.06 & & & & & & & \\
\hline
\end{tabular}


Table 11 (Continued). Yield ( $\mathrm{g}$ of FA) of milk FA of cows fed varying proportions of tomato seed and whole cottonseed

\begin{tabular}{|c|c|c|c|c|c|c|c|c|c|c|c|c|}
\hline \multirow[b]{2}{*}{ FA } & \multirow[b]{2}{*}{ Parity $^{1}$} & \multicolumn{4}{|c|}{ Treatment $^{2}$} & \multirow[b]{2}{*}{ SEM } & \multirow[b]{2}{*}{$\mu^{3}$} & \multicolumn{5}{|c|}{$P$-value ${ }^{4}$} \\
\hline & & $\mathrm{TS}$ & HTS & LTS & WCS & & & $\mathrm{TE}$ & $\mathrm{PE}$ & $\mathrm{PE} \times \mathrm{TE}$ & $\mathrm{L}$ & $\mathrm{Q}$ \\
\hline \multirow[t]{2}{*}{ cis-9 and cis-10 C18:1 } & $\mathrm{P}$ & 204.52 & 210.16 & 250.17 & 238.68 & 17.00 & 230.35 & 0.06 & 0.65 & 0.82 & 0.03 & 0.87 \\
\hline & M & 224.60 & 225.20 & 247.20 & 242.26 & & & & & & & \\
\hline \multirow[t]{2}{*}{ cis-11 C18:1 } & $\mathrm{P}$ & 7.94 & 7.31 & 7.69 & 7.76 & 0.29 & 7.52 & 0.52 & 0.55 & 0.9993 & 0.73 & 0.20 \\
\hline & M & 7.60 & 7.04 & 7.35 & 7.50 & & & & & & & \\
\hline \multirow{2}{*}{ cis-12 C18:1 } & $\mathrm{P}$ & 4.45 & 4.51 & 5.32 & 5.72 & 0.82 & 5.42 & 0.02 & 0.27 & 0.65 & 0.01 & 0.03 \\
\hline & $\mathrm{M}$ & 5.58 & 5.03 & 5.68 & 7.03 & & & & & & & \\
\hline \multirow[t]{2}{*}{ cis-13 C18:1 } & $\mathrm{P}$ & 0.65 & 0.71 & 0.83 & 0.77 & 0.09 & 0.78 & 0.11 & 0.32 & 0.54 & 0.08 & 0.35 \\
\hline & M & 0.81 & 0.67 & 0.87 & 0.90 & & & & & & & \\
\hline \multirow[t]{2}{*}{ trans-16 C18:1 } & $\mathrm{P}$ & 3.80 & 4.00 & 4.72 & 5.10 & 0.64 & 4.71 & 0.001 & 0.17 & 0.93 & 0.0002 & 0.38 \\
\hline & M & 4.31 & 4.74 & 5.43 & 5.54 & & & & & & & \\
\hline \multirow{2}{*}{$\mathrm{C} 18: 2$} & $\mathrm{P}$ & 49.42 & 49.27 & 50.58 & 50.19 & 2.06 & 48.85 & 0.16 & 0.58 & 0.43 & 0.31 & 0.15 \\
\hline & M & 48.21 & 44.07 & 49.28 & 49.80 & & & & & & & \\
\hline \multirow[t]{2}{*}{$\mathrm{C} 20$} & $\mathrm{P}$ & 1.88 & 2.13 & 2.14 & 2.02 & 0.18 & 1.96 & 0.04 & 0.49 & 0.39 & 0.02 & 0.19 \\
\hline & M & 1.64 & 1.78 & 2.13 & 1.98 & & & & & & & \\
\hline \multirow{2}{*}{ C18:3n-6 } & $\mathrm{P}$ & 0.46 & 0.47 & 0.49 & 0.52 & 0.06 & 0.51 & 0.03 & 0.07 & 0.21 & 0.01 & 0.62 \\
\hline & M & 0.47 & 0.48 & 0.63 & 0.59 & & & & & & & \\
\hline \multirow{2}{*}{ C18:3n-3 } & $\mathrm{P}$ & 11.14 & 11.06 & 10.96 & 11.43 & 0.33 & 11.06 & 0.76 & 0.89 & 0.82 & 0.63 & 0.49 \\
\hline & M & 11.43 & 10.39 & 11.04 & 11.01 & & & & & & & \\
\hline \multirow[t]{2}{*}{ cis-9,trans-11 C18:2 } & $\mathrm{P}$ & 8.33 & 7.12 & 5.41 & 5.07 & 1.27 & 5.79 & 0.17 & 0.04 & 0.30 & 0.03 & 0.74 \\
\hline & M & 5.59 & 4.63 & 5.02 & 5.12 & & & & & & & \\
\hline \multirow{2}{*}{ trans-10,cis-12 C18:2 } & $\mathrm{P}$ & 0.03 & 0.10 & 0.14 & 0.04 & 0.04 & 0.08 & 0.42 & 0.96 & 0.20 & 0.38 & 0.23 \\
\hline & M & 0.07 & 0.07 & 0.07 & 0.10 & & & & & & & \\
\hline \multirow{2}{*}{ All trans $\mathrm{C} 18: 2$} & $\mathrm{P}$ & 0.15 & 0.18 & 0.11 & 0.18 & 0.04 & 0.18 & 0.62 & 0.47 & 0.92 & 0.68 & 0.93 \\
\hline & M & 0.22 & 0.24 & 0.16 & 0.17 & & & & & & & \\
\hline \multirow{2}{*}{$\mathrm{C} 20: 3$} & $\mathrm{P}$ & 2.21 & 1.99 & 2.16 & 2.17 & 0.19 & 2.27 & 0.18 & 0.35 & 0.86 & 0.63 & 0.06 \\
\hline & M & 2.44 & 2.19 & 2.44 & 2.57 & & & & & & & \\
\hline C20:4 & $\mathrm{P}$ & 2.98 & 2.79 & 2.83 & 2.80 & 0.16 & 2.78 & 0.22 & 0.70 & 0.22 & 0.75 & 0.08 \\
\hline & M & 2.70 & 2.45 & 2.80 & 2.92 & & & & & & & \\
\hline C20:5 & $\mathrm{P}$ & 0.75 & 0.61 & 0.75 & 0.66 & 0.10 & 0.77 & 0.42 & 0.22 & 0.80 & 0.97 & 0.38 \\
\hline & M & 0.85 & 0.79 & 0.87 & 0.88 & & & & & & & \\
\hline C22:4n-6 & $\mathrm{P}$ & 0.72 & 0.82 & 2.44 & 0.67 & 0.65 & 0.86 & 0.32 & 0.15 & 0.41 & 0.63 & 0.41 \\
\hline & $\mathrm{M}$ & 0.55 & 0.53 & 0.63 & 0.52 & & & & & & & \\
\hline $\mathrm{C} 22: 5 n-6$ & $\mathrm{P}$ & 0.32 & 0.17 & 0.26 & 0.18 & 0.05 & 0.25 & 0.47 & 0.40 & 0.30 & 0.18 & 0.63 \\
\hline & M & 0.27 & 0.29 & 0.24 & 0.26 & & & & & & & \\
\hline C22:5n-3 & $\mathrm{P}$ & 1.60 & 1.49 & 1.48 & 1.51 & 0.07 & 1.52 & 0.78 & 0.98 & 0.62 & 0.88 & 0.46 \\
\hline & M & 1.48 & 1.41 & 1.60 & 1.57 & & & & & & & \\
\hline $\mathrm{C} 22: 6$ & $\mathrm{P}$ & 0.18 & 0.14 & 0.18 & 0.18 & 0.04 & 0.14 & 0.90 & 0.20 & 0.93 & 0.52 & 0.91 \\
\hline & M & 0.06 & 0.10 & 0.13 & 0.12 & & & & & & & \\
\hline Unknown & $\mathrm{P}$ & 46.75 & 49.75 & 49.47 & 43.88 & 3.40 & 48.67 & 0.50 & 0.61 & 0.15 & 0.39 & 0.87 \\
\hline & M & 54.01 & 44.51 & 50.69 & 50.28 & & & & & & & \\
\hline Total & $\mathrm{P}$ & 1,429 & 1,452 & 1,506 & 1,467 & 61.92 & $1,479.5$ & 0.08 & 0.82 & 0.45 & 0.07 & 0.58 \\
\hline & $\mathrm{M}$ & 1,460 & 1,393 & 1,578 & 1,551 & & & & & & & \\
\hline${ }^{1} \mathrm{P}=$ primiparous; $\mathrm{M}$ & & & & & & & & & & & & \\
\hline $\begin{array}{l}{ }^{2} \mathrm{TS}=\text { tomato seed as } \\
\text { cottonseed as lipid su }\end{array}$ & TMP & $\begin{array}{l}\text { at in TMR } \\
=\text { whole }\end{array}$ & $\begin{array}{l}\mathrm{HTS}=50 \\
\text { ttonseed }\end{array}$ & $\begin{array}{l}\text { tomato se } \\
\text { as } 100 \%\end{array}$ & $\begin{array}{l}: 50 \% \text { wh } \\
\text { the lipid }\end{array}$ & $\begin{array}{l}\text { ttonse } \\
\text { lement }\end{array}$ & $\begin{array}{l}\text { as lipid } \\
\text { n TMR. }\end{array}$ & nen & $\mathrm{n} T$ & $\mathrm{TS}=25^{\circ}$ & nato se & $\%$ whol \\
\hline${ }^{3} \mu=$ overall mean. & & & & & & & & & & & & \\
\hline${ }^{4}$ Probability of a signif & reatmen & $\mathrm{TE})$, parity & $(\mathrm{PE})$, trea & nent $\times$ pal & $y$ interacti & or a lin & $r(\mathrm{~L})$ or & ratic & ect o & tment. & & \\
\hline
\end{tabular}




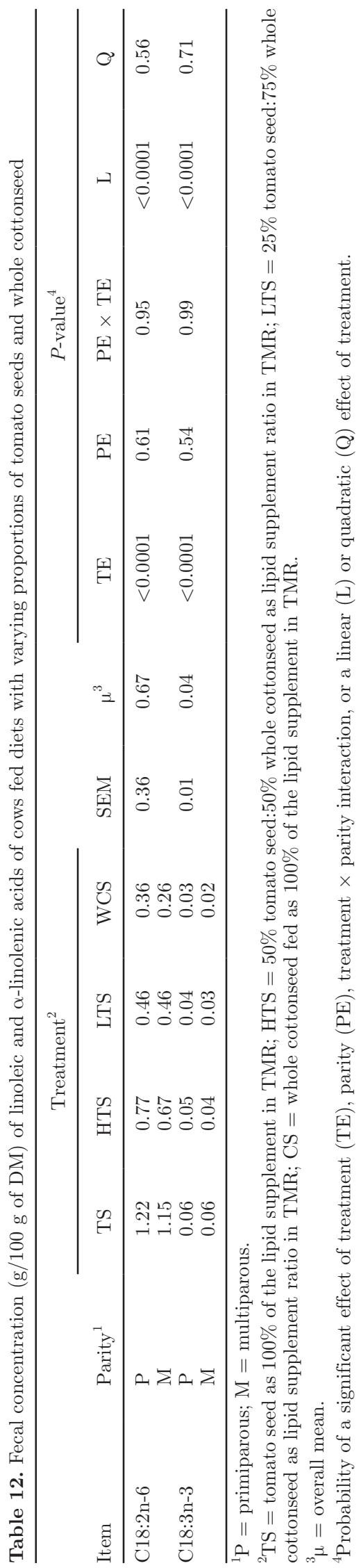

WCS decreased. Yields of trans- $6+8$ C18:1, trans-9 C18:1, trans-12 C18:1, trans-13 + 14 C18:1, trans-16 $\mathrm{C} 18: 1$, and cis-12 $\mathrm{C} 18: 1(P<0.01)$ also increased as the proportion of WTS to WCS decreased, suggesting that shift in biohydrogenation caused by a change in some microbial populations in the rumen might have occurred. McKain et al. (2010) demonstrated that Butyrivibrio fibrisolvens JW11 converted trans-10, cis-12 C18:2 to trans-10 C18:1, but there was also conversion to trans-12 C18:1 and cis-12 C18:1. Both trans-12 C18:1 and cis-12 C18:1 were increased with WCS, a possible indication that biohydrogenation occurred via the alternate pathway that involved Propionibacterium acnes and trans-10 C18:1. With cis-9,trans-11 C18:2 as the substrate for $B$. fibrisolvens JW 11, there was no trans-12 $\mathrm{C} 18: 1$ and cis-12 C18:1 produced.

If WCS caused a shift to the alternate pathway for biohydrogenation, why did the yield of cis-9,trans 11 C18:2 increase and the yield of C18:0 decrease with increasing dietary WTS? If the rate-limiting step in this pathway is the conversion of trans-11 C18:1 to C18:0, this might suggest that the microbial population responsible for this step might have been inhibited. Butyrivibrio proteoclasticus reduced trans- 11 C18:1 to C18:0 (Paillard et al., 2007). In culture, B. fibrisolvens removed little trans-11 C18:1, and P. acnes DSM 1897 removed essentially no trans-11 C18:1 (McKain et al., 2010). However, B. proteoclasticus P-18 removed approximately $40 \%$ of the trans-11 C18:1 substrate with some conversion to C18:0 and removed $93 \%$ of the cis-9 C18:1 with substantial conversion to C18:0. Potu et al. (2011) used continuous-culture fermenters and reported that soybean oil had no effects on the growth of $B$. fibrisolvens and B. proteoclasticus, the latter the only known bacteria to convert trans C18:1 to C18:0. In contrast, PUFA were toxic to $B$. proteoclasticus (Paillard et al., 2007). If $B$. proteoclasticus was inhibited, yield of C18:0 might be reduced and yield of cis-9,trans-11 C18:2 increased. This does not explain why the conversion of cis-9,trans-11 C18:2 to trans-11 C18:1 was reduced because this conversion is believed to be rapid (Harvatine and Allen, 2006).

\section{CONCLUSIONS}

Intake of DM and milk yield did not differ with dietary treatment. Concentration of milk fat decreased and yield of milk fat tended to decrease as WTS increased even though total FA intake across diets did not differ. Intakes of $\mathrm{CP}$, total FA, C18:2, and $\mathrm{C} 18: 3$ were not different for diet. However, whole-tract apparent digestibility of $\mathrm{CP}$, total FA, C18:2, and C18:3 decreased with increasing proportion of WTS to WCS. The decreased total FA digestibility with WTS was re- 
flected in the lower yields of C18:0 and cis-9 and cis-10 C18:1, FA in milk fat that are derived preformed or in the case of cis-9 C18:1 derived also from desaturase of C18:0. Both MUN and PUN decreased with increasing WTS, possibly indicating a reduced degradability of WTS protein in the rumen, although rumen ammonia was not measured to support this comment. The amount of intake $\mathrm{N}$ retained in total milk $\mathrm{N}$ was similar across diets, so the lower CP digestibility did not affect production performance and likely did not affect microbial growth in the rumen because apparent digestibility of DM, ash-free NDF, and intake energy did not differ for diet. Concentration and yield of selected FA differed. Milk concentration of C18:3 increased and C18:2 tended to increase with WTS. However, total milk yields of these $2 \mathrm{FA}$ did not differ, which might suggest that a small amount of WTS lipid that escaped the rumen was digested in the small intestine to provide postruminal $\mathrm{C} 18: 2$ and $\mathrm{C} 18: 3$, but the amount was small because no effect on yield of these 2 FA occurred. Changes in yields of trans and cis C18:1 FA could reflect shifts in rumen biohydrogenation pathways. Finally, decreased whole-tract apparent digestibility of total FA, C18:2, and C18:3, as well as the lower concentration and yield of milk fat observed with increased WTS to WCS, suggests lower postruminal availability of WTS lipid. Research is needed on WTS fed at higher levels and in the wet form. More information is needed on the digestibility of protein and lipid in WTS. Finally, the analytical issue associated with EE and WTS is interesting to explore.

\section{ACKNOWLEDGMENTS}

The authors thank S. Cunningham, P. Domer, D. Gall, D. Gisi, G. Johnson, J. Pisenti, M. Rubio, F. Sauers, M. Simmons, and J. Villasenor for their help with the animals and the diets. Thank you to undergraduates A. Hines, V. Leonardes, and H. Smith for help with feeding cows and collecting samples. This was the master's thesis project of C. A. Cassinerio, who was supported by scholarships from the California chapter of the American Registry of Professional Animal Scientists. A gift from The Morning Star Company (Woodland, CA) supported this research.

\section{REFERENCES}

Abbeddou, S., B. Rischkowsky, M. E. Hilali, H. D. Hess, and M. Kreuzer. 2011a. Influence of feeding Mediterranean food industry byproducts and forages to Awassi sheep on physicochemical properties of milk, yoghurt and cheese. J. Dairy Res. 78:426-435.

Abbeddou, S., S. Riwahi, L. Iniguez, M. Zaklouta, H. D. Hess, and M. Kreuzer. 2011b. Ruminal degradability, digestibility, energy content, and influence on the nitrogen turnover of various Mediter- ranean by-products in fat-tailed Awassi sheep. Anim. Feed Sci. Technol. 163:99-110.

California Department of Food and Agriculture. 2012. Agricultural Statistical Overview 2011-2012, California Agricultural Statistics Review 1-100. Accessed Sep. 30, 2012. http://www.cdfa.ca.gov/ Statistics/.

Andrews, R. J., and D. Lewis. 1970. The utilization of dietary fats by ruminants. I. The digestibility of some commercially available fats. J. Agric. Sci. (Camb.) 75:47-53.

AOAC International. 1995. Official Methods of Analysis. 16th ed. AOAC Int., Arlington, VA.

Brodowski, D., and J. R. Geisman. 1980. Protein content and amino acid composition of protein of seeds from tomatoes at various stages of ripeness. J. Food Sci. 45:228-229., 240.

Chumpawadee, S., and O. Pimpa. 2009. Effects of non forage fiber sources in total mixed ration on feed intake, nutrient digestibility, chewing behavior and ruminal fermentation in beef cattle. J. Anim. Vet. Adv. 8:2038-2044.

Del Valle, M., M. Camara, and M. E. Torija. 2003. Effect of pomace addition on tomato paste quality. Acta Hortic. 613:399-406.

Del Valle, M., M. Camara, and M. E. Torija. 2006. Chemical characterization of tomato pomace. J. Sci. Food Agric. 86:1232-1236.

Del Valle, M., M. Camara, and M. E. Torija. 2007. The nutritional and functional potential of tomato by-products. Acta Hortic. 758:165-172.

DePeters, E. J., J. B. German, S. J. Taylor, S. T. Essex, and H. Perez-Monti. 2001. Fatty acids and triacylglycerol composition of milk fat from lactating Holstein cows in response to supplemental canola oil. J. Dairy Sci. 84:929-936.

Ellinger, S., J. Ellinger, and P. Stehle. 2006. Tomatoes, tomato products and lycopene in the prevention and treatment of prostate cancer: Do we have the evidence from intervention studies? Curr. Opin. Clin. Nutr. Metab. Care 9:722-727.

Fondevila, M., J. A. Guada, J. Gasa, and C. Castrilla. 1994. Tomato pomace as a protein supplement for growing lambs. Small Rumin. Res. 13:117-126.

Harvatine, K. J., and M. S. Allen. 2006. Fat supplements affect fractional rates of ruminal fatty acid biohydrogenation and passage in dairy cows. J. Nutr. 136:677-685.

Hinman, N. H., W. N. Garrett, A. K. Swareton, and N. C. East. 1978. Tomato pomace scores well as sheep feed. Calif. Agric. 32:12-13.

King, A. J., and G. Zeidler. 2004. Tomato pomace may be a good source of vitamin $\mathrm{E}$ in broiler diets. Calif. Agric. 58:59-62.

Knoblich, M., B. Anderson, and D. Latshaw. 2005. Analyses of tomato peel and seed byproducts and their use as a source of carotenoids. J. Sci. Food Agric. 85:1166-1170.

Latlief, S. J., and D. Knorr. 1983. Tomato seed protein concentrates: Effects of methods of recovery upon yield and compositional characteristics. J. Food Sci. 48:1583-1586.

Littell, R. C., G. A. Milliken, W. W. Stroup, and R. D. Wolfinger. 1996. SAS Systems for Mixed Models. SAA Inst. Inc., Cary, NC.

Marsh, W. H., B. Fingerhut, and E. Kirsch. 1957. Determination of urea nitrogen with the diacetyl method and an automatic dialyzing apparatus. Tech. Bull. Regist. Med. Technol. 27:239-246.

McKain, N., K. J. Shingfield, and R. J. Wallace. 2010. Metabolism of conjugated linoleic acids and C18:1 fatty acids by ruminal bacteria: Products and mechanisms. Microbiology 156:579-588.

Morad, M. M., A. H. El-Tamimi, A. H. Rady, and S. S. Ibrahim. 1980. Tomato seed oil II. Evaluation of the Egyptian tomato seed oil and the residual meal. Fette Seifen Anstrichmittel. 82:122-124.

Paillard, D., N. McKain, M. T. Rincon, K. J. Shingfield, D. I. Givens, and R. J. Wallace. 2007. Quantification of ruminal Clostridium proteoclasticum by real-time PCR using a molecular beacon approach. J. Appl. Microbiol. 103:1251-1261.

Palmquist, D. L., and T. C. Jenkins. 2003. Challenges with fats and fatty acid methods. J. Anim. Sci. 81:3250-3254.

Potu, R. B., A. A. AbuGhazaleh, D. Hastings, K. Jones, and S. A. Ibrahim. 2011. The effect of lipid supplements on ruminal bacteria in continuous culture fermenters varies with the fatty acid composition. J. Microbiol. 49:216-223 
Robertson, J. B., and P. J. Van Soest. 1981. The detergent system of analysis and its application to human foods. Pages 123-158 in The Analysis of Dietary Fiber in Foods. W. P. T. James and O. Theander, ed. Marcel Dekker, New York, NY.

SAS Institute Inc. 2011. SAS/STAT 9.3 User's Guide. SAS Inst. Inc., Cary, NC.

Schieber, A., F. C. Stintzing, and R. Carle. 2001. Byproducts of plant food processing as a source of functional compounds-recent developments . Trends Food Sci. Technol. 12:401-413. (Review).

Schneider, B. H., and W. P. Flatt. 1975. The Evaluation of Feeds Through Digestibility Experiments. The University of Georgia Press, Athens.

Turakhozhaev, M. T., R. A. Alibekova, S. R. Rakhmetova, L. P. Zubkova, and T. T. Shakirov. 1979. Isolation of protein from tomato seed meal. J. Chem. Nat. Comp. 15:734-736.

Van Soest, P. J., and J. B. Robertson. 1991. Methods of dietary fiber, neutral detergent fiber, and nonstarch polysaccharides in relation to animal nutrition. J. Dairy Sci. 74:3583-3597.
Weiss, W. P., D. L. Frobose, and M. E. Koch. 1997. Wet tomato pomace ensiled with corn plants for dairy cows. J. Dairy Sci. 80:2896-2900.

Yaseen, A. A. E., M. H. A. Shams El-Din, and A. R. Abd El-Latif 1991. Fortification of balady bread with tomato seed meal. Cereal Chem. 68:159-161.

Yuangklang, C., K. Vauspen, S. Wongsuthavas, P. Panyakaew, A. Alhairdary, H. E. Mohamed, and A. C. Beyen. 2010a. Growth performance in beef cattle fed rations containing dried tomato pomace. J. Anim. Vet. Advan. 9:2261-2264.

Yuangklang, C., K. Vauspen, S. Wongsuthavas, S. Bureenok, P. Panyakaew, A. Alhairdary, H. E. Mohamed, and A. C. Beynen. 2010b. Effect of replacement of soybean meal by dried tomato pomace on rumen fermentation and nitrogen metabolism in beef cattle. Am. J. Agric. Biol. Sci. 5:256-260.

Ziaei, N., and S. Molaei. 2010. Evaluation of nutrient digestibility of wet tomato pomace ensiled with wheat straw compared to alfalfa hay in Kermani sheep. J. Anim. Vet. Adv. 9:771-773. 